\title{
Contribution to the sedimentology of the Messinian carbonates of the Chelif Basin (Boukadir, Algeria)
}

\author{
Meriem L. MOUlanA ${ }^{1,2, *}$, Aurélia HUBERT-FERRARI ${ }^{1}$, Mostefa GUENDOUZ ${ }^{2}$, Meriam EL OUAHABI ${ }^{3}$, \\ ABDELHAK BOUTALEB ${ }^{4} \&$ FRÉDÉRIC BOULVAIN $^{5}$
}

\author{
${ }_{2}^{1}$ Department of Geography, University of Liège, Allée du VI Août 2, 4000 Liège, Belgium. \\ ${ }^{2}$ Faculty of Earth Sciences, Geographical and Territorial Planning, University of Science and Technology Houari Boumediene, \\ (USTHB), El Alia, BP 32, Bab Ezzouar, 16111 Algiers, Algeria. \\ ${ }^{3}$ UR Clay, Sediment Geochemistry and Environment (AGEs), Department of Geology, Agora Quarter, Building B18, Allée du VI \\ Août 14, University of Liège, 4000 Liège, Belgium. \\ ${ }^{4}$ Metallogeny and magmatism laboratory of Algeria (LMMA) -ATRST. FSTGAT- USTHB El Alia, BP 32, Bab Ezzouar, 16111 \\ Algiers, Algeria. \\ ${ }^{5}$ Sedimentary Petrology, Department of Geology, University of Liège, B20, Agora Quarter, Allée du VI Août, 12, 4000 Liège, \\ Belgium. \\ "corresponding author: meriemmoulana@gmail.com.
}

\begin{abstract}
The Messinian (Upper Miocene) is characterized at the level of its marginal basins by the development of numerous carbonate platforms. This study concerns the Messinian platform of the Boukadir region in the south of the Chelif Basin in Algeria. It is composed of a lower prograding rimmed platform and an upper aggradational homoclinal ramp resting upon the Tortonian-Lower Messinian Blue Marl Formation, and its thickness reaches $\sim 280 \mathrm{~m}$ in the Chelif Basin. The upper red-algae unit is uniform and subhorizontal with a minimum thickness of $90 \mathrm{~m}$. Petrographic analysis of the upper ramp reveals three different microfacies, characterized by Lithothamnium, foraminifera, high porosity, and a microsparitic matrix. MF1 is a packstone, MF2 a packstone/bindstone deposited above the fair-weather wave base and MF3 is a wackestone to packstone deposited below this level. The upper unit is made up entirely of autochthonous biogenic elements without significant external fluvial contribution. It was formed in a shallow marine environment, with very high productivity and a significant export of the sediments produced. This aggradation was followed by a rapid exhumation (regression) transforming all the aragonite into calcite. The platforms correspond to the T2 complex reef formation (6.7-5.95 Ma) documented on the other Messinian carbonate platforms in the South of the Alboran Sea that formed just before the Messinian Salinity Crisis.
\end{abstract}

KEYWORDS: carbonates, ramp, Miocene, Ouarsenis, Mediterranean, microsparitic, microfacies, aggradation.

\section{Introduction}

The Messinian is known above all for the Messinian Salinity Crisis (MSC), a key period in the evolution of the Mediterranean Sea where dramatic changes occurred between 5.94 and 5.33 million years ago. The MSC is characterized by the disconnection of the Mediterranean Sea from the Atlantic Ocean, which caused a large sea-level fall and a thick accumulation of evaporites within the basin center (Hsü et al., 1973; Ryan et al., 1973; CIESM, 2008; Mascle \& Mascle, 2019). Whether the disconnection was continuous or discontinuous is still highly debated (Hsü et al., 1977; Rouchy \& Saint-Martin, 1992; Clauzon et al., 1996; Krijgsman et al., 1999; Riding et al., 1999; Roveri et al., 2014). Because of the high popularity of the controversy, emphasis has partly shifted away from other specificities of the Messinian, the enhancement of biogenic productivity, in relation to the progressive closure of the Betic and Rifian gateways between the Atlantic Ocean and the Mediterranean Sea (Krijgsman et al., 2018). Large diatomiterich deposits (Pellegrino et al., 2018) and carbonate complexes (Esteban, 1979; Saint-Martin \& Rouchy, 1990) were deposited before the MSC along the margins of the Mediterranean Sea. In addition, Terminal Carbonate Complexes (TCC) were also deposited synchronously with the precipitation of Primary Lower Gypsum (PLG) in peripheral basins/margins around the Mediterranean during MSC Stage 1 (5.94-5.6 Ma; Roveri et al., 2014). All these biogenic deposits are well recorded in the Neogene sediments within the marginal basins in SE Spain, NE Morocco, and NW Algeria (Roger et al., 2000; Cornée et al., 2004).

In marginal basins, the Messinian biogenic deposits show strong variations depending on the local morphology of the subbasins, terrestrial sediment supply, upwelling, and other environmental factors like sea temperature and salinity. Their correlation in a given basin or across the Mediterranean Sea as well as their attribution to a given stage can be difficult. In addition, several types of Messinian carbonate platforms exist even if prograding-aggrading ramp platforms are particularly well developed (Montenat \& Ott D'Estevou, 1994; Cornée et al., 1994). The first correlation of carbonate platforms across the Mediterranean has been proposed by Cornée et al. (2004). In the Chelif Basin in Algeria, the Messinian carbonate deposits are particularly large and well exposed (Perrodon, 1957) with a variable thickness from a few dozens of meters to about 130 meters (Saint-Martin \& Rouchy, 1990). They have been well studied in the western part of the Chelif Basin near the city of Oran (Saint-Martin et al., 1983, 1992, 1995; Saint-Martin, 1996, 2008; Cornée et al, 1994; Babinot \& Boukli-Hacene, 1998; Atif et al., 2008; Naimi et al., 2020).

In the present study, we focus on the thickest Messinian carbonate deposits of the Chelif Basin. They crop out on its southern margin in the Boukadir region, south of the Chelif River in the piedmont of the Ouarsenis Mountain. Two main interpretations were proposed. Neurdin-Trescartes $(1992,1995)$ considered that the upper carbonate formation is synchronous with the Primary Lower Gypsum deposited in the basin during stage 1 of the MSC and is thus a terminal carbonate complex (TCC). This interpretation is different from other studies on the Messinian Carbonates in the Chelif Basin that considered that most carbonate platforms and reefs occurred in open normal marine conditions and are synchronous with diatomite rich deposits (i.e Tripoli Formation) and anterior to gypsiferous deposits of the MSC (e.g. Cornée et al., 2004; Arab et al., 2015). TCC of the MSC were still documented on the margin of the Chelif Basin, for example on top of the Murdjadjo Platform (Cornée et al., 2004), and in Djebel Diss (Mostaganem, NW Algeria; Belhadji et al., 2008). The TCC characteristics are different from previously deposited open marine carbonate platforms. The TCC were deposited in a confined restricted infralittoral high salinity environment characterized by the occurrence of stromatolites, oolitic deposits, and microbial 
limestones (Cornée et al, 2004; Saint-Martin, 2008)

The aim of the study is to better characterize the carbonate deposits in the Boukadir area and to reconstitute their depositional environment using thin sections, field work, and satellite images. It would allow us (1) to compare it with other Messinian carbonates of the Chelif Basin, (2) to correlate this carbonate margin with other Messinian carbonate sections in the Mediterranean Basin, and (3) to re-valuate its age.

\section{Geological Setting}

The Chelif Basin $\left(56,000 \mathrm{~km}^{2}\right)$ in northern Algeria is a guttershaped basin being elongated in an ENE-WSW direction. It extends over a length of $260 \mathrm{~km}$ and a width of $35 \mathrm{~km}$ between the Sebkha of Oran to the west and Chlef city to the east (Fig. 1). The basin is bounded to the south by the Tellian Mountains, which include, from west to east, the mountains of Tessala-Ouled Ali, Beni Chougrane, and Ouarsenis. The northern margin of the basin is delimited by the mounts of Djebel Murdjadjo, Arzew, and Djebel Diss. On the northeastern edge of the basin, the Dahra Massif presently forms a large anticlinal structure (Rouchy et al., 2007). The epi-metamorphic schists from the Massif of Doui limit the Chelif Basin to the east.

The Chelif Basin is an intracontinental basin on top of the nappes affected by stacks that sustained different phases of deformation (Leprêtre et al., 2018). The basin is filled by more than $4 \mathrm{~km}$ of Miocene to Quaternary marine and continental sediments (Rouchy et al., 2007). The first infill was attributed to Miocene sediments of Aquitanian-Burdigalian age (NeurdinTrescartes, 1992) and later re-evaluated to be LanghianSerravalian by Belkebir et al. (2008). It displays a complete sedimentary record of the MSC at the Miocene-Pliocene transition (Anderson, 1936; Perrodon, 1957; Rouchy, 1982). It was a marginal basin of the Mediterranean Sea during that period.

The Upper Miocene occupies most of the Chelif Basin. During the Tortonian and the lower Messinian, the sedimentation is characterized by the deposition of mostly blue marls that can reach a thickness of $500 \mathrm{~m}$ and that can locally be preceded by conglomerates (Anderson 1936; Perrodon, 1957; Rouchy, 1982; Moissette, 1988, 1993; Saint-Martin \& Rouchy, 1990; Mansour et al., 1995; Neurdin-Trescartes, 1995). In the Blue Marl Formation, up to three levels of volcanic ash (cinerites) can be found and were dated between 8.6 and 9.4 Ma by ${ }^{40} \mathrm{Ar} /{ }^{39} \mathrm{Ar}$, confirming their deposition during the Tortonian (Mansour et al., 2008).

During the Messinian, the blue marls were overlain by the transgressive, up to $200 \mathrm{~m}$ thick series of diatomite-rich deposits called the Tripoli unit, and then by up to a $400 \mathrm{~m}$ thick gypsumrich formation (Perrodon, 1957; Belkebir et al., 1996; Rouchy et al., 2007) (Fig. 1). Towards the proximal margins, the diatomite formation is partially covered and laterally passes to algae and/ or coral limestones and locally to sandstones (Anderson, 1936; Perrodon, 1957; Rouchy, 1982; Moissette, 1988, 1993; SaintMartin \& Rouchy, 1990; Mansour et al., 1995). Above the Messinian series, Pliocene marls are gradually passing into marine sandstone sediments attesting for the large Zanclean transgression due to the full reconnection of the Mediterranean Sea to the Atlantic Ocean (Rouchy et al., 2007) (Fig. 1).

In this study, we focus on the carbonate formation standing above the Tortonian to lower Messinian Blue Marl Formation in the Boukadir region, first mapped by Perrodon (1957) and, more

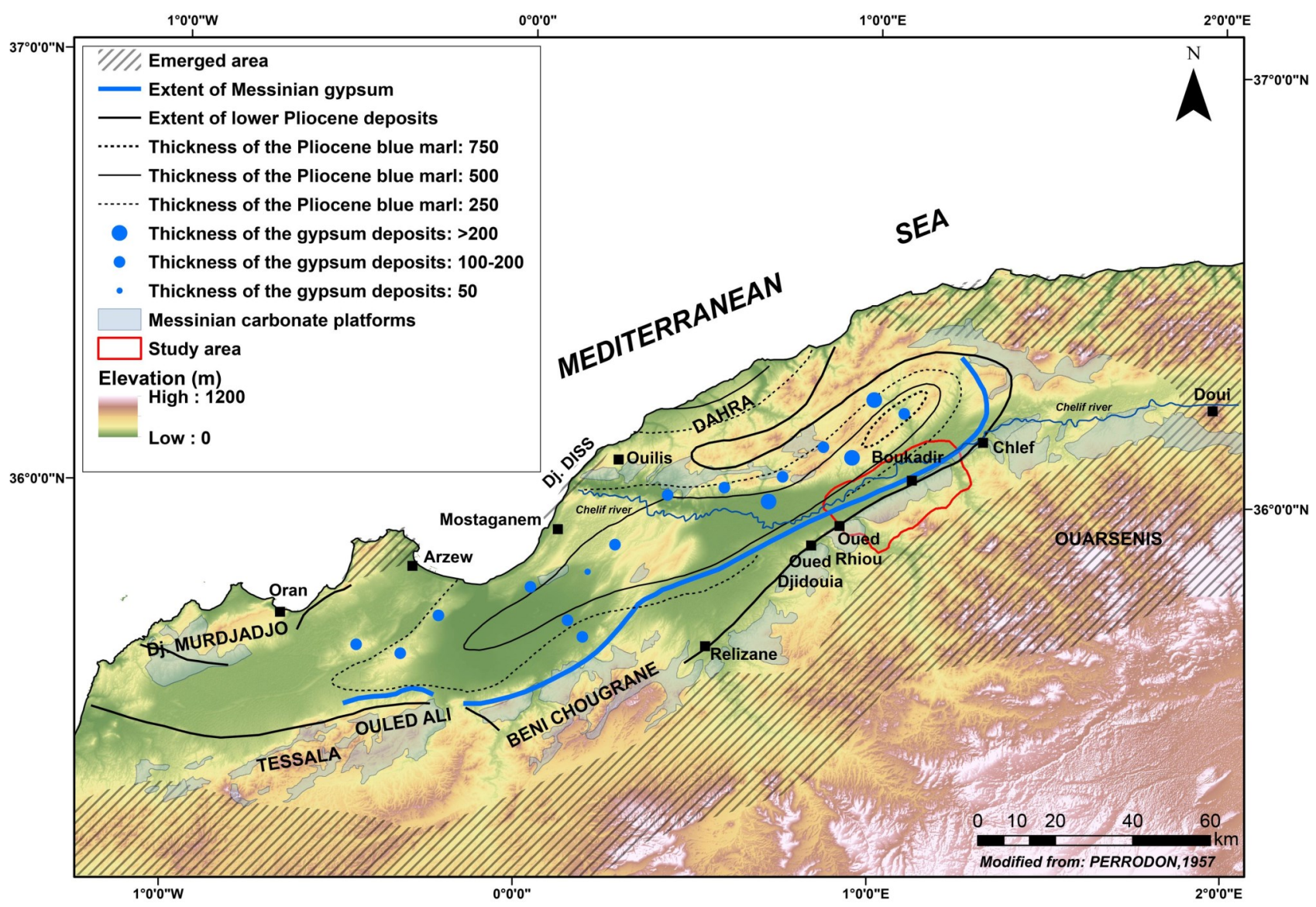

Figure 1. The Chelif Basin through the Late Miocene and Early Pliocene (modified from Perrodon, 1957; Rouchy et al., 2007). Topography source: Jarvis et al. (2008) 
specifically, on its uppermost carbonate unit. These Messinian Carbonates are located on the southeastern margin of the Chelif Basin but were never extensively studied before (Fig. 1). Along the Ouarsenis piedmont, the carbonate formation is outcropping over $85 \mathrm{~km}$, from the city of Oued Fodda (east of Doui) to the east to the city of Oued Djidouia to the west. The formation is covered to the north, in the Chelif Basin by Pliocene marine to continental sediments and by the Quaternary alluvial sediments of the Chelif River.

In our study area, the reference section of NeurdinTrescartes (1992) (section A; Fig. 2) shows that the Upper Miocene Ouarsenis piedmont is composed of three different units (Fig. 3):

\section{Tortonian-Messinian Blue Marls Formation (Unit 1)}

This formation corresponds to grey-bluish marls up to 500 $\mathrm{m}$ thick. A few tens of meters below the top, Neurdin-Trescartes (1992) found a cinerite level (C3) of $4 \mathrm{~m}$ thick dated from 11.87 $\pm 0.76 \mathrm{Ma}$ (Belkebir et al., 2008). This level of cinerite shows an alternation of coarse volcanic ashes enriched in mica and fine, less micaceous cinerite associated with clay. The dip of this unit is about $5^{\circ}$ to the north at the location of the log of Neurdin-Trescartes (1992) (section A; Fig. 2).

\section{Messinian bioclastic carbonate unit (Unit 2)}

It is $\sim 70 \mathrm{~m}$ thick and is rich in fossils. From the bottom, there are:

- $6 \mathrm{~m}$ of bioclastic carbonates containing Ostrea, pectens, and burrows;

- $1 \mathrm{~m}$ of bioclastic carbonates with a few Lithothamnium;

- $3 \mathrm{~m}$ of bioclastic carbonates with an increasing amount of
Lithothamnium;

- $2.6 \mathrm{~m}$ of crumbly bioclastic carbonates with a large number of Lithothamnium and at the layer bottom, a $0.50 \mathrm{~m}$ thick bed of algal oncoids;

- $1.30 \mathrm{~m}$ of light grey, finer-grained calcareous bioclastic carbonates with fewer Lithothamnium;

- $19 \mathrm{~m}$ of bioclastic carbonates rich in macrofauna (pectens, gastropods, sea urchin), with the occurrence of few pebbles; the layer top displays a thinner grain size with numerous burrows;

- $4 \mathrm{~m}$ of pink bioclastic carbonates with imprints of small bivalves and the presence of micas;

- $4 \mathrm{~m}$ of bioclastic carbonate beds containing serpulae;

- $6 \mathrm{~m}$ of bioclastic carbonates with pectens and serpulae;

- $8 \mathrm{~m}$ of crumbly marly bioclastic carbonate flags;

- $20 \mathrm{~m}$ of bioclastic carbonate slabs.

At the level of section A along Oued Rhiou, NeurdinTrescartes (1992) measured a dip of $35^{\circ}$ to the north (Fig. 2).

Neurdin-Trescartes $(1992,1995)$ called the above unit, the "El-Bordj" Formation and considered that it changed laterally along the Chelif margin in the Tripoli Formation characterized by diatomite deposits.

Lithothamnium carbonate unit (Unit 3)

Unit 2 is covered by an upper carbonate unit, which comprises at least $80 \mathrm{~m}$ of Lithothamnium carbonates outcropping along the Ouarsenis piedmont. Unit 3 was called the "Oued Sig" Formation by Neurdin-Trescartes (1992, 1995), and shows a strong uniformity. This unit was deposited during a regression according to Neurdin-Trescartes (1979) and

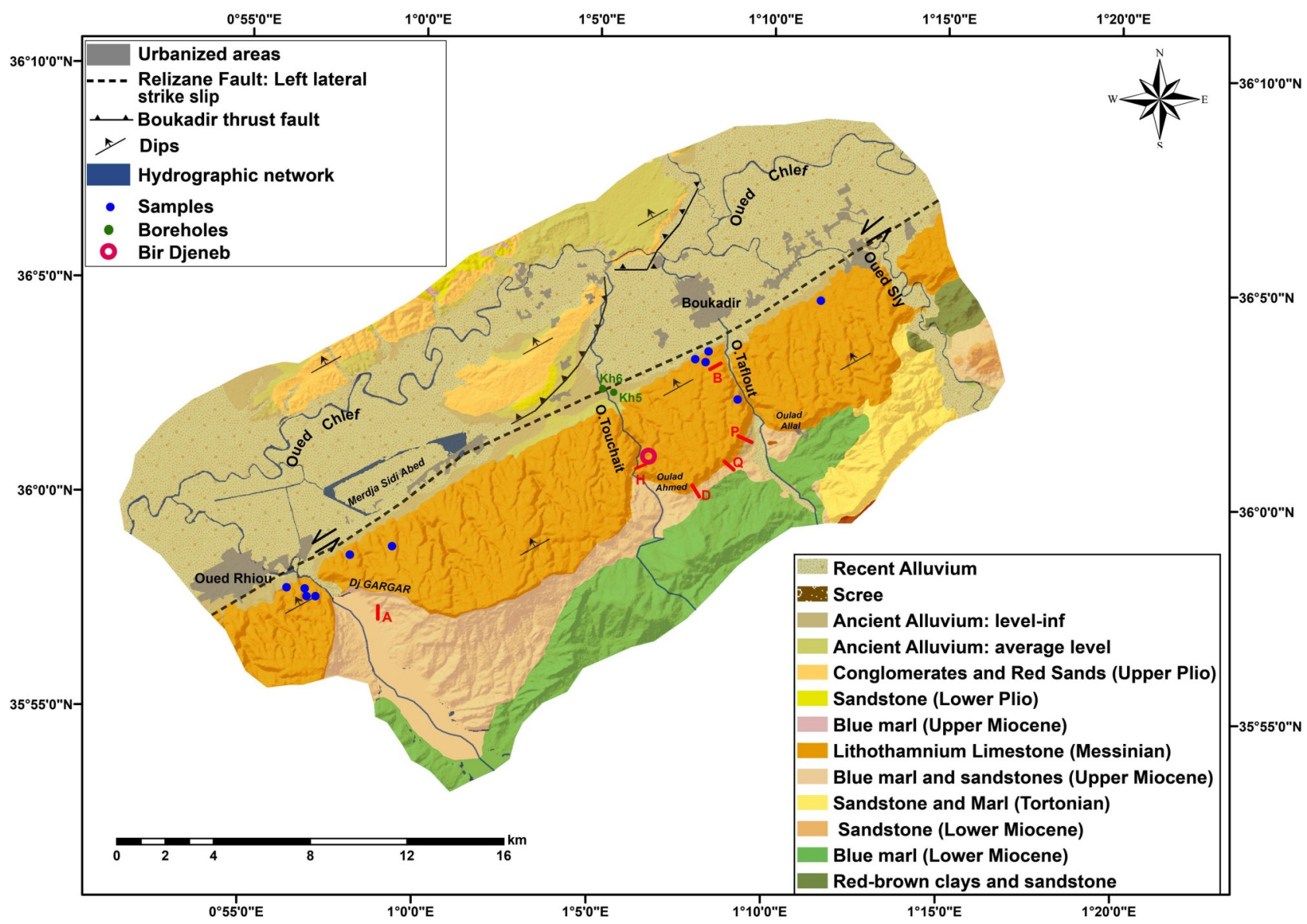

Figure 2. Geological map of the study area modified from Brives \& Ferrand (1912). This region refers to the "Study area" reported in Fig.1. Samples analyzed in the present study are indicated in blue. Geological section A corresponds to one section of Neurdin-Trescartes (1992), other geological sections were investigated by the authors. 


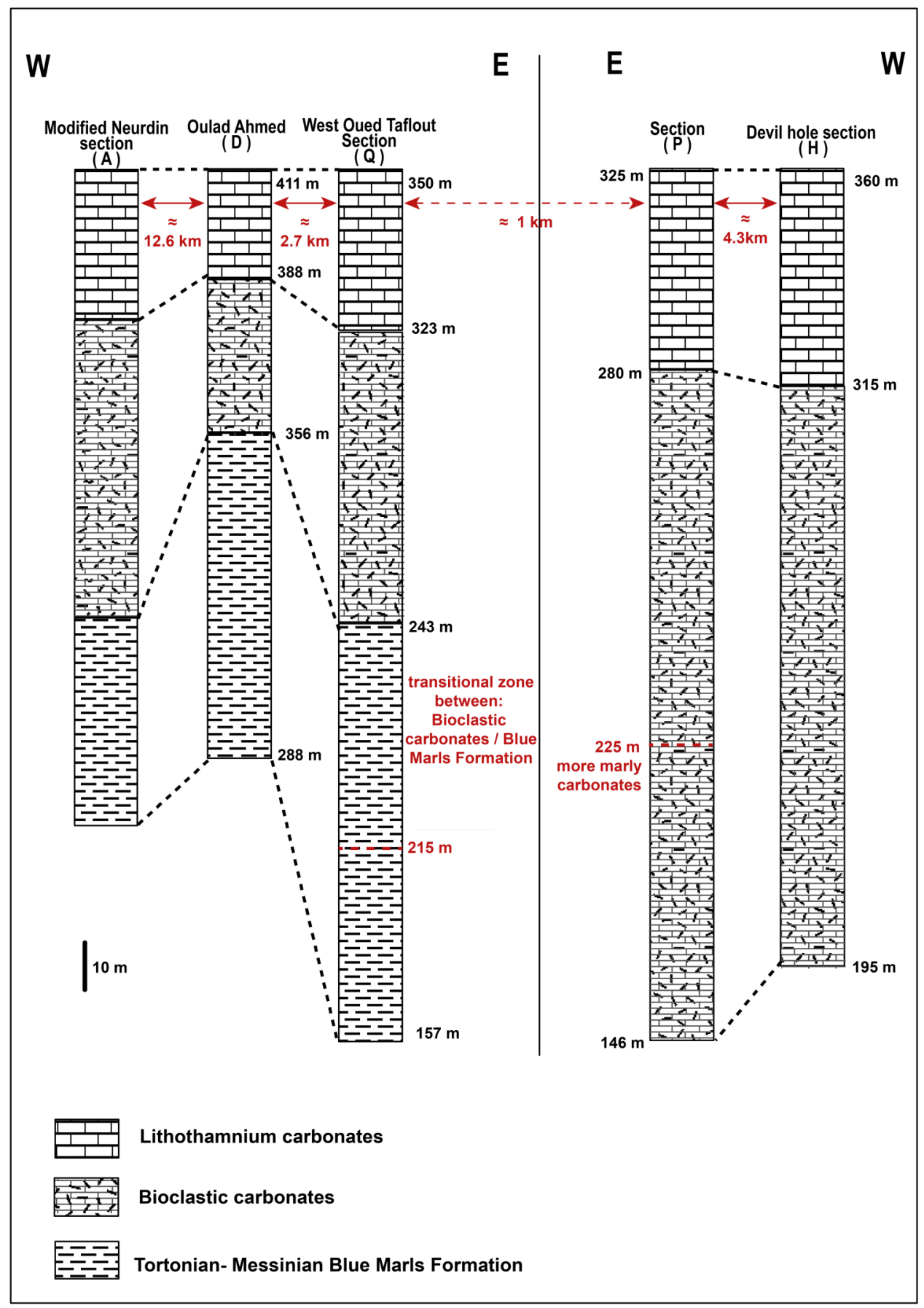

Figure 3. Geological cross sections investigated in the field (for the location of sections D, Q, P, H, see Fig. 2) and by NeurdinTrescartes (1992) along Oued Rhiou (reference section A). In section $\mathrm{P}$ at $225 \mathrm{~m}$, the bottom of the lower carbonate unit is composed of marly carbonates with few bioclastic layers. In sections $\mathrm{D}$ and $\mathrm{Q}$, we also have a gradational transition at the bottom of the lower unit to the Blue Marls Formation.

corresponds to the main part of the present work. At the level of section A, Neurdin-Trescartes (1992) documented a subhorizontal dip. Over the whole Ouarsenis Piedmont, we also measured systematically a subhorizontal dip. NeurdinTrescartes (1992, 1995) considered that the "Oued Sig" Formation graded into gypsum-bearing sediments deposited during the MSC in the deeper part of the Chelif Basin. We would re-evaluate this hypothesis.

Along the mountain front, the carbonate platform is cut by the left-lateral Relizane (sinistral) strike-slip fault that strikes $\mathrm{N} 70^{\circ} \mathrm{E}$, a direction identical to the strike of the Chelif Basin. The fault runs over $150 \mathrm{~km}$ from the city of Chlef to the city of Relizane (Fig. 1) (Meghraoui et al., 1986). In the study area, the Boukadir thrust fault ends near the Relizane Fault. The thrust strikes $\mathrm{N} 50^{\circ} \mathrm{E}$ and bounds the Boukadir anticlinal structure along which Pliocene sandstones and conglomerates crop out in the Chelif Basin (Fig. 2).

\section{Materials \& methods}

The geological setting of Boukadir region is still poorly known, and more precisely the mode of deposition of the carbonates at the front of the Ouarsenis piedmont. The results presented in this work are based on the analysis of nineteen samples located in Figure 2 (blue dots), the evaluation of the platform geometry based on Google Earth (GE) images, and limited field work. We also used two deep drill holes Kh5, Kh6 that reach the depths of $376 \mathrm{~m}$ and $\approx 1910 \mathrm{~m}$ respectively (BURGAP, 2004). Sample names and locations are displayed in the Appendix.

We examined the lithology of the upper Lithothamnium carbonate unit in three quarries present along the Ouarsenis front. The unit is composed of homogeneous tuffaceous carbonates with no visible lithological change (color, grain size) (Fig. 4), and no change in macroscopic sedimentary features. All lithological sections investigated in the Lithothamnium unit 

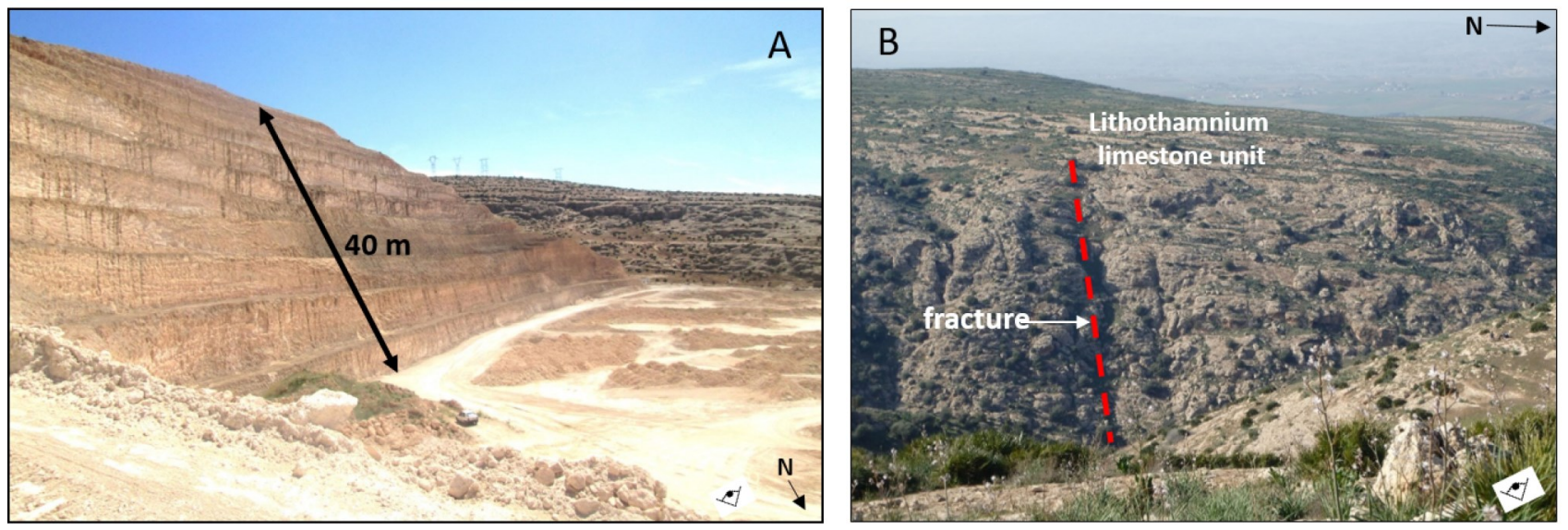

Figure 4. The upper Lithothamnium carbonate unit characterized by lithological homogeneity. A. Lithothamnium unit $40 \mathrm{~m}$ thick in the Sidi Abed quarry $\left(35^{\circ} 59^{\prime} 36.65^{\prime \prime} \mathrm{N} / 1^{\circ} 00^{\prime} 11.34\right.$ 'E) in the western part of the study area. B. Subhorizontal bedding in the Lithothamnium unit, near Devil Hole near section $\mathrm{H}$ in Fig. 2.

at the front of the Ouarsenis Massif were similar and homogenous. We thus did not report any precise lithological column at the sampling locations.

We investigated the homogeneity of the Lithothamnium unit using thin sections and X-ray diffractometry (XRD) / X-ray fluorescence spectrometry (XRF) analyses, first in section and second laterally along the piedmont. We sampled a reference section near the Taflout River, south of Boukadir city along the piedmont front (Fig. 2). The Taflout section is $80 \mathrm{~m}$ high and composed of eight samples with $10 \mathrm{~m}$ intervals (PVR00 at the top to PVR07 at the bottom). Petrographic analyses were done based on the samples and their thin sections. Facies nomenclature and description are based on Embry \& Klovan (1971). Eleven other samples were taken along the piedmont from east to west also for petrographic analysis. Among them, four samples were taken just north of the Taflout section (ECH8) and come from the Boukadir tuff quarry $(153,154$, and 156), located very close to the reference section (Fig. 2).

Eleven selected thin sections were analyzed by cathodoluminescence microscopy (CITL MK5). Eight samples come from the $80 \mathrm{~m}$ high Taflout section (PVR00, PVR01, PVR02, PVR03, PVR04, PVR05, PVR06 and PVR07) and three samples from Boukadir tuff quarry (153, 154 and 156).

Bulk mineralogical (XRD) analyses were performed on 17 samples (ECH1, ECH2, ECH3, ECH6, ECH7, ECH8, ECH9，153，154，156，PVR00, PVR01，PVR02， PVR03, PVR04, PVR05, PVR06, and PVR07) according to the following experimental procedure. The bulk samples were dried at $40{ }^{\circ} \mathrm{C}$ for 48 hours, and then ground and sieved through a mesh of $<250 \mu \mathrm{m}$ size fraction (Moore \& Reynolds, 1989). The mineralogical phases present in the powdered samples were identified by X-ray diffraction using a powder Brucker D8Advance diffractometer, with $\mathrm{Cu}$ anticathode (University of Liège, Belgium). The angular range is between $2^{\circ}$ and $60^{\circ} 2 \Theta$. The X-ray patterns were treated by the DIFFRAC plus EVA software. Mineral phases were determined semi-quantitatively $( \pm 5 \%)$.

Chemical characterization of major and minor elements of three samples $(153,154$, and PVR01) was carried out, using a portable X-ray fluorescence spectrometer ( $\mathrm{p}-\mathrm{XRF}$ ). Our purpose was to have a more quantitative assessment of the terrigenous material $(\mathrm{Si}, \mathrm{Al})$ present in the upper Lithothamnium unit with respect to the biogenic $(\mathrm{Ca})$ material. Based on XRD results, we selected one sample PVR01 that was containing the highest percentage of terrigenous material (quartz, K-feldspar, plagioclase) and two homogeneous samples having no terrigenous material. Thermo Fischer Nitron XL3t with a
'GOLDD' detector (Mineralogy Laboratory, University of Liège) was used. The $\mathrm{p}$-XRF was placed against the sample and $\mathrm{X}$-rays were generated when the nose cone was in direct contact with the surface. The X-ray spot size was $3 \mathrm{~mm}$ in diameter. The X-ray tube has an Ag anode of $50 \mathrm{kV}$ and $200 \mu \mathrm{A}$. The lightest detectable element is $\mathrm{Mg}$. The standardization mode selected is the $\mathrm{Cu} / \mathrm{Zn}$ Mining. This analysis mode uses four separate filters (high and low filters) having different counting times with a total measurement time of $75 \mathrm{~s}$ per analysis. The software utilizes a Fundamental Parameters algorithm to determine the concentrations of each element. The spectra and concentration values obtained from the XLT3 were downloaded to a computer for analysis. Each sample was measured three times and the average values are given.

An analysis of the architecture of the carbonate platform was carried out along the Ouarsenis foothills from east to west using (1) a digital terrain model with a resolution of $12.4 \mathrm{~m}$, as well as (2) GE imagery that allows to track individual beds across the landscape. The Digital Elevation Model used was the ALOS PALSAR Digital Elevation Model (DEM). A total of four swath topographic profiles were first drawn on the ArcGIS 10.5.1 software, then the extraction of the altitude points was performed in the GNU Octave, version 4.4.1 software with a program for this purpose. Topographic swath profiles are constructed by projecting equally spaced topographic profiles within a strip or swath of $200 \mathrm{~m}$ (Baulig, 1926; Tricart \& Cailleux, 1958; D’Agostino et al., 2001; Fielding et al., 1994). These profiles provide a general view of the topographic pattern of the carbonates deposits and have been widely used to characterize regional-scale morphology (D'Agostino et al., 2001; Riquelme et al., 2003; Grohmann, 2005; Molin et al., 2004, 2012; Scotti et al., 2014; Azañón et al., 2015). The GE imagery allows studying the architecture of the upper Lithothamnium unit and its relation with the lower bioclastic unit previously deposited.

\section{Results}

\subsection{Petrographic analyses}

The petrographic analyses done on the thin sections along the piedmont (19 samples) (Fig. 5) reveal three different microfacies. The first microfacies, MF1, is the most frequent (samples PVR00, PVR01, PVR02, PVR04, PVR05, PVR06, $154,156, \mathrm{ECH} 01, \mathrm{ECH} 03, \mathrm{ECH} 04, \mathrm{ECH} 05$, and $\mathrm{ECH} 7$ ), it is a bioclastic packstone to wackestone with mainly microsparitic matrix, and micritic matrix in samples PVR00 and PVR06. It is 

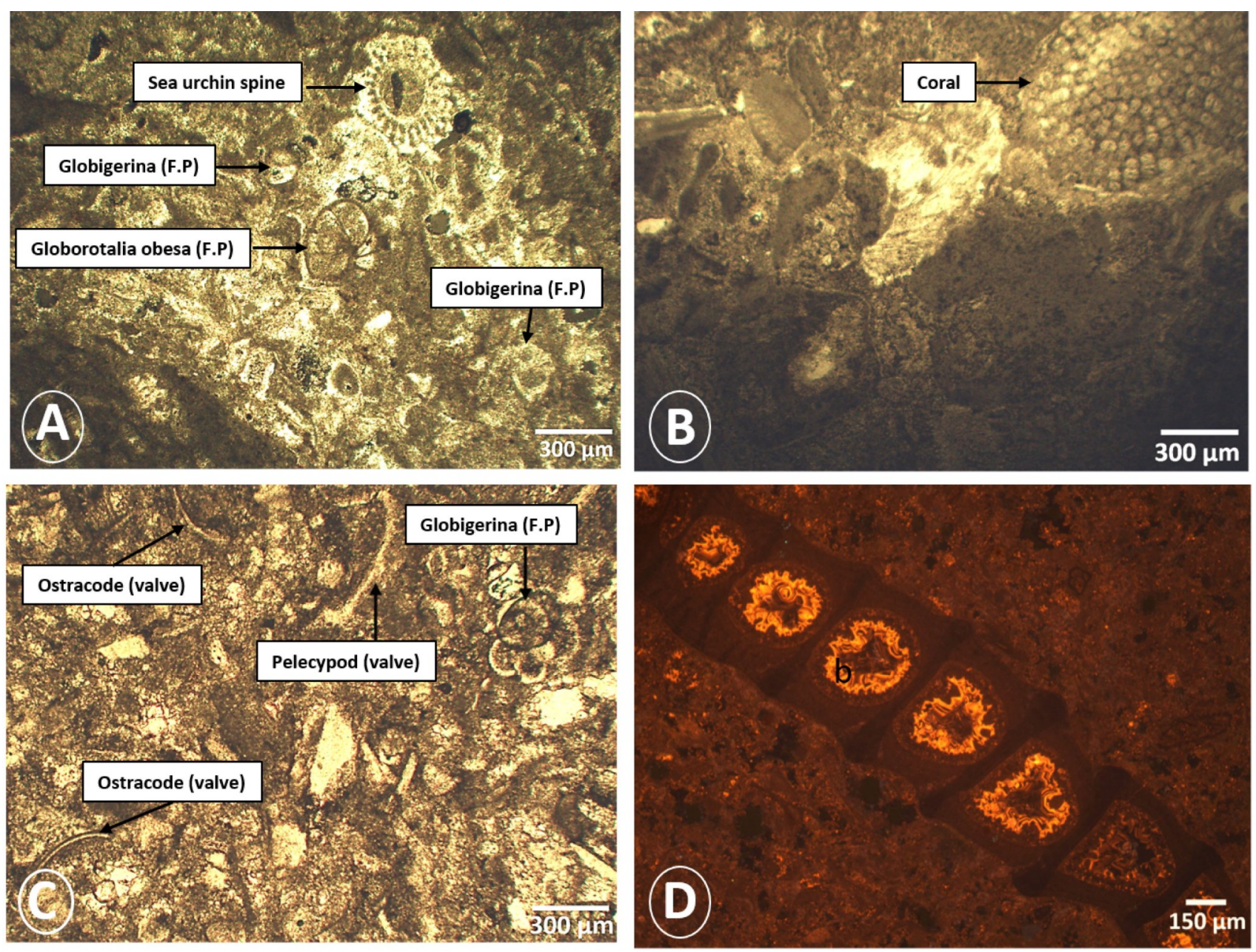

Figure 5. Photomicrograph showing: A. fossils from sample 156 (MF1); B. debris of coral from sample ECH08 (MF2); C. fossils from sample ECH02 (MF3); D. cathodoluminescence microscopy showing a bryozoan with internal luminescent cement (MF3).

characterized by syntaxial cement and drusic cement in sample 154. MF1 is poorly sorted, its grain size is $\geq 300 \mu \mathrm{m}$. It contains numerous broken fossils and some intact: echinoderms, foraminifera, bryozoans, gastropods, Lithothamnium, arthropods, brachiopods, scaphods, pelecypods, and pieces of phosphate (vertebrate), and also peloids, oncoliths, rhodoliths. The second microfacies MF2 (samples PVR03, 153, ECH06, and $\mathrm{ECH08)}$ is a bindstone to packstone to grainstone with microsparitic matrix and syntaxial cement and red algae pattern. MF2 is moderately sorted and its grain size is $\leq 300 \mu \mathrm{m}$. Its fossils assemblage includes Lithothamnium, oncoliths, pelecypods, echinoderms, foraminifera, and a coral debris. The last microfacies, MF3 (PVR07 and ECH02) is a bioclastic packstone to wackestone with fine-grained elements and a microsparitic matrix. It is well sorted, and it includes pelecypods, Lithothamnium, and foraminifera.

\subsection{Cathodoluminescence and cement analysis}

The most common cement type is syntaxial overgrowth on echinoderm fragments. In cathodoluminescence, all types of cement of our samples are non-luminescent except the sample PVR07 (MF2) of the Taflout section taken at $106 \mathrm{~m}$ of altitude (Table 1). A bryozoan shows internal cementation in zoecia (carbonated wall of bryozoan), which starts with a dog-tooth non-luminescent cement, followed by a zoned luminescent overgrowth. The non-luminescence of the calcitic cement together with multiple zonations (Amieux, 1982) point towards a phreatic meteoric origin of the cement, although non- luminescence of calcitic cement can also be related to the relative abundance of $\mathrm{Fe}$ in the crystals (Hemming et al., 1989; Swart, 2015). The XRF results of the samples indicate that there is not enough $\mathrm{Fe}$ available to suppress the luminescence, indeed iron contents of up to $1 \%(\mathrm{FeO})$ are not sufficient to suppress luminescence (Frank et al., 1982; Hemming et al., 1989).

\subsection{Chemical and mineralogical compositions}

Mineralogical analysis by XRD (Table 2) revealed that the samples are mostly composed of calcite ( $\sim 94$ to 100\%) with some trace of quartz $(\sim 1 \%)$.

Only the PVR01 sample of the Taflout section taken at 166 $\mathrm{m}$ of altitude (Appendix) reveals a slightly higher amount of terrigenous material with $94 \%$ of calcite, $3 \%$ of quartz, $1 \%$ of plagioclase, and $1 \%$ of $\mathrm{K}$-feldspar.

The XRF analyses of three samples (153, 154, and PVR01) indicate that the most abundant element is calcium with an average value of $96.04 \pm 2.91 \%$. We also note the presence of $2.75 \%$ of silica in the sample PVR01 (Table 3), which is in agreement with the mineralogical results.

\subsection{Architecture of the carbonate units based on topography, remote sensing, and field data}

We combined a topographic analysis with section measurements, bedding traced on Google Earth imagery, and drilling data to unravel the first-order geometry of the two carbonate units. 
Table 1. Main characteristics of the three microfacies.

\begin{tabular}{|c|c|c|c|c|c|c|}
\hline $\mathbf{N}^{\circ}$ & Texture & Fossils assemblage & Grain-size & Sorting & Cement and/or matrix & Samples \\
\hline MF1 & $\begin{array}{l}\text { packstone to } \\
\text { wackestone }\end{array}$ & $\begin{array}{l}\text { echinoderms, foraminifera, } \\
\text { bryozoans, gastropods, } \\
\text { Lithothamnium, arthropods, } \\
\text { oncoliths, rhodoliths, } \\
\text { brachiopods, peloids, scaphods, } \\
\text { pieces of phosphate (vertebrate), } \\
\text { pelecypods }\end{array}$ & $\geq 300 \mu \mathrm{m}$ & poorly sorted & $\begin{array}{l}\text { mainly microsparitic } \\
\text { matrix and micritic } \\
\text { matrix in PVRO0 and } \\
\text { PVR06, with a syntaxial } \\
\text { and drusic cement, }\end{array}$ & $\begin{array}{l}\text { PVR00, PVR01, PVR02, } \\
\text { PVR04, PVR05, PVR06, } \\
\text { 154, 156, ECH01, ECH03, } \\
\text { ECH04, ECHO5 and ECH07 }\end{array}$ \\
\hline MF2 & $\begin{array}{l}\text { bindstone to } \\
\text { packstone locally } \\
\text { grainstone }\end{array}$ & $\begin{array}{l}\text { Lithothamnium, oncoliths, } \\
\text { pelecypods, echinoderms, } \\
\text { foraminifera, debris of coral }\end{array}$ & $\leq 300 \mu \mathrm{m}$ & $\begin{array}{l}\text { moderately } \\
\text { sorted }\end{array}$ & $\begin{array}{l}\text { microsparitic matrix } \\
\text { and syntaxial cement }\end{array}$ & $\begin{array}{l}\text { PVR03, 153, ECH06 } \\
\mathrm{ECH} 05 \text {, and } \mathrm{ECH} 8\end{array}$ \\
\hline MF3 & $\begin{array}{l}\text { packstone to } \\
\text { wackestone }\end{array}$ & $\begin{array}{l}\text { pelecypods, Lithothamnium, } \\
\text { foraminifera }\end{array}$ & - & well sorted & microsparitic matrix & PVRO7 and ECHO2 \\
\hline
\end{tabular}

The upper carbonate unit dips toward the northeast with its lowest elevation at the contact with the alluvial sediment of the Chelif Basin around $79 \mathrm{~m}$. At its highest elevation 5 to $6 \mathrm{~km}$ more to the south, it forms a scarp where the whole carbonate sequence resting upon the blue marl can be found. The top of the sequence at that location changes from $375 \mathrm{~m}$ in the east to $680 \mathrm{~m}$ in the west. The relief of the carbonate margin changes from $230 \mathrm{~m}$ in the east to $540 \mathrm{~m}$ in the west. The difference in relief along strike does not correspond to a variation in thickness of the carbonate formation (Fig. 3).

To the west, the down-cutting of Oued Rhiou provides a 525 $\mathrm{m}$ high section and the clearest view of the lower unit overlain by the upper Lithothamium unit. Bedding traced on Google Earth images and section A logged by Neurdin-Trescartes
(1992) unravel a platform architecture with $35^{\circ}$ beds of the lower complex at the level of the section A close to the reservoir waters and an unconformity with the $5^{\circ}$ beds of the upper unit (Fig. 6 B1, B2).

East of Oued Rhiou, at the level of the scarp, the beds of the lower carbonate unit are nearly flat and conformable with the upper unit (Fig. 6 A1, A2, A3). The remote sensing interpretation is confirmed by our field observation at the location of the Oulad Ahmed section (D) $\left(36^{\circ} 02^{\prime} 05.56^{\prime \prime} \mathrm{N} / 1^{\circ}\right.$ 09'43.35"E; Fig. 2), located $12 \mathrm{~km}$ more to the NE. Section D is still located along the scarp and shows a conformable contact between the upper Lithothamnium carbonate unit and the bioclastic carbonate unit (Fig. 3, Fig.7-A). At that location, the lower unit is $35 \mathrm{~m}$ thick and has a low dip $\left(5\right.$ to $\left.10^{\circ}\right)$ (Fig. $7 \mathrm{~A}$ ).

\begin{tabular}{lcccc}
\hline Samples & Quartz (\%) & Calcite (\%) & K-feldspar (\%) & Plagioclase (\%) \\
\hline Ech 1 & 0.6 & 99.4 & 0.0 & 0.0 \\
Ech 2 & 0.0 & 100.0 & 0.0 & 0.0 \\
Ech 3 & 0.6 & 99.4 & 0.0 & 0.0 \\
Ech 6 & 0.0 & 100.0 & 0.0 & 0.0 \\
Ech 7 & 0.0 & 100.0 & 0.0 & 0.0 \\
Ech 8 & 0.0 & 100.0 & 0.0 & 0.0 \\
Ech 9 & 0.0 & 100.0 & 0.0 & 0.0 \\
P 153 & 0.3 & 99.7 & 0.0 & 0.0 \\
P 154 & 0.3 & 99.7 & 0.0 & 0.0 \\
PV00 & 0.1 & 99.9 & 0.0 & 0.0 \\
PV01 & 3.2 & 94.5 & 0.9 & 1.4 \\
PV02 & 9.3 & 99.7 & 0.0 & 0.0 \\
PV03 & 1.1 & 98.9 & 0.0 & 0.0 \\
PV04 & 9.5 & 0.0 & 0.0 \\
PV05 & 0.5 & 99.5 & 0.0 & 0.0 \\
PV06 & 0.0 & 100.0 & 0.0 & 0.0 \\
PV07 & 9.2 & 99.8 & 0.0 & 0.0 \\
Average & 1.5 & 98.5 & $\mathbf{0 . 1}$ & $\mathbf{0 . 1}$ \\
Standard deviation & $\mathbf{0 . 8}$ & $\mathbf{9 9 . 4}$ & &
\end{tabular}

Table 2. Results of the mineralogical analysis of the 17 samples based on X-ray diffraction (XRD). 


\begin{tabular}{|c|c|c|c|c|c|}
\hline & 153 & 154 & PVR01 & Average & Standard deviation \\
\hline $\mathrm{Ca}(\%)$ & 95.45 & 99.20 & 93.48 & 96.04 & 2.91 \\
\hline Si (\%) & 1.63 & 0.52 & 2.75 & 1.63 & 1.12 \\
\hline P (\%) & 0.10 & 0.06 & 0.06 & 0.07 & 0.03 \\
\hline S (\%) & 0.04 & 0.05 & 0.30 & 0.13 & 0.15 \\
\hline V (\%) & 0.01 & 0.01 & 0.01 & 0.01 & 0.00 \\
\hline $\mathrm{Fe}(\%)$ & 0.23 & 0.13 & 0.42 & 0.26 & 0.15 \\
\hline $\operatorname{Sr}(\%)$ & 0.03 & 0.03 & 0.04 & 0.03 & 0.01 \\
\hline K (\%) & 0.09 & $<$ LOD & 0.24 & 0.16 & 0.12 \\
\hline Mg (\%) & 2.05 & $<L O D$ & 1.99 & 2.02 & 1.17 \\
\hline $\mathrm{Al}(\%)$ & 0.36 & $<$ LOD & 0.71 & 0.54 & 0.36 \\
\hline
\end{tabular}

Table 3. Results of XRF analysis of the selected samples. LOD: Limit of detection.
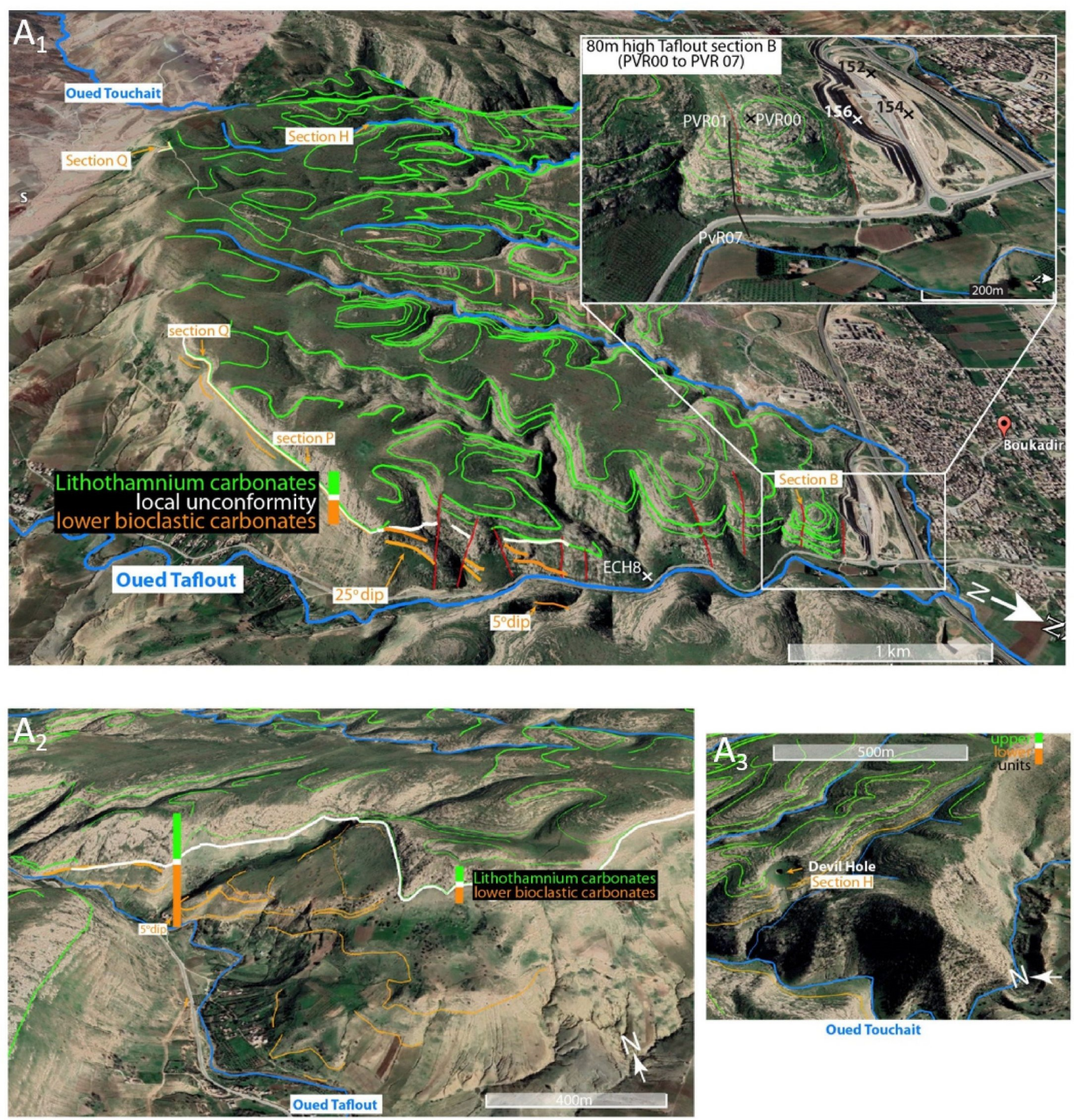

Oued Touchait

Figure 6. Google Earth image (GE) (3x vertical exaggeration) showing a disconformity between the upper subhorizontal unit and the lower unit $\left(5^{\circ}\right.$ in A2 to $35^{\circ}$ in A1) in front of Oued Taflout (A1 + A2), in front of Oued Touchait (A3), and in front of Oued Rhiou (B1 + B2 [see next page]). Green lines: beds of the upper unit drawn on Google Earth. Orange lines: beds of the lower unit drawn on Google Earth. Blue lines: river network. 

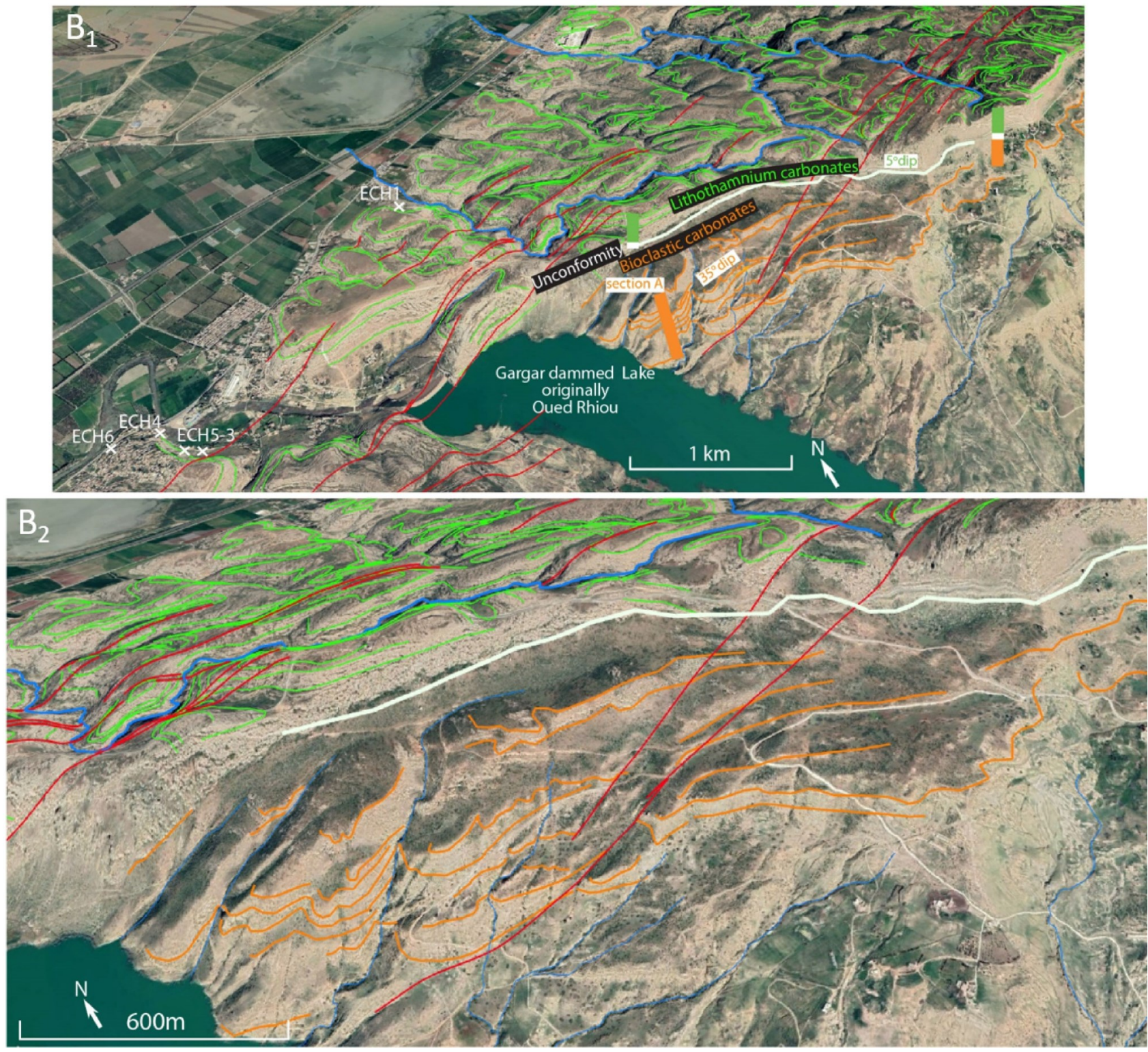

Figure 6 (continued).

It shows rapid changes in facies (grain size, bioclastic content, terrigenous fraction): the upper half is characterized by large bioturbations (burrows) and the occurrence of 20-30 cm thick coarser-grained bioclastic layers with numerous bivalves interpreted as tempestites (Fig. 7 C-D); the lower part shows the increasing occurrence of marls. The transition to the underlying Blue marl Formation is gradational. The upper Lithothamnium unit is conformable and composed of $\sim 23 \mathrm{~m}$ thick massive carbonate beds. About $2 \mathrm{~km}$ more to $\mathrm{WNW}$ of Section D, another section called H $\left(36^{\circ} 01.367^{\prime} \mathrm{N} / 1^{\circ} 09.096^{\prime} \mathrm{E}\right)$ (Fig. 6 A1, A3) can be drawn near the location of the Devil Hole, a $73 \mathrm{~m}$ deep karstic pit (Figs 2 and 3) (Birebent, 1947). Above the pit, the upper Lithothamnium unit is visible and $45 \mathrm{~m}$ thick. The 73 $\mathrm{m}$ deep pit is carved mostly into the lower bioclastic unit until $252 \mathrm{~m}$ a.s.l. and near its base, it has a low dip according to speleological observations (Birebent, 1947). The adjacent Oued Touchait river valley incising into the same unit reaches $195 \mathrm{~m}$ a.s.1., which implies that the lower unit is at least $120 \mathrm{~m}$ thick (Fig. 3). About $3.5 \mathrm{~km}$ more to the $\mathrm{NE}$ at the location of the 220 $\mathrm{m}$ deep downcutting of Oued Taflout, the lower and upper carbonate units are also visible on both sides of the river. The section Q $\left(36^{\circ} 01.367^{\prime} \mathrm{N} / 1^{\circ} 09.096^{\prime} \mathrm{E}\right)$ (Fig. $\left.6 \mathrm{~A} 1\right)$ revealed that the upper unit is $35 \mathrm{~m}$ thick and the lower unit is $60 \mathrm{~m}$ thick
(Fig. 3). Farther northeast, still along Oued Taflout, the lower unit has a $25^{\circ}$ dip visible in the landscape (Fig.7 B) and on the GE view (Fig. $6 \mathrm{~A} 1$ ) and is unconformably overlain by the low dipping upper Lithothamnium unit. At the location of section $\mathrm{P}$ $\left(36^{\circ} 01.812^{\prime} \mathrm{N} / 1^{\circ} 09.268^{\prime} \mathrm{E}\right)$ (Fig. 3 and Fig. $\left.6 \mathrm{~A} 1\right)$, the upper unit is $42 \mathrm{~m}$ thick and the lower one has an apparent $138 \mathrm{~m}$ thickness. On the other side of the river, near the village of Oulad Allal $\left(36^{\circ} 01 ' 58.73\right.$ 'N / $\left.1^{\circ} 09^{\prime} 46.12^{\prime \prime} \mathrm{E}\right)$, the lower unit is locally composed of bioclastic layers part with serpulas and numerous shells (Fig.7 D); and shows a gradational transition to the Blue Marls Formation. Along the Ouarsenis front and at the location of section $\mathrm{B}$, the only visible unit is the $80 \mathrm{~m}$ thick subhorizontal upper Lithothamnium unit (Fig. 6 A1). In the Chelif Basin, at the location of the $\sim 1000 \mathrm{~m}$ boreholes Kh5 $\left(36^{\circ}\right.$ 04’39.6509” N / 1'04'27.7095” E) and Kh6 (360'⒏0890” N / $1^{\circ} 05^{\prime} 14.1997^{\prime}$ 'E), situated less than $1 \mathrm{~km}$ north of the surface contact between the carbonates and the alluvium, the carbonate formation is found at depths of $126 \mathrm{~m}$ and $147 \mathrm{~m}$ respectively and extends until the depth of $376 \mathrm{~m}$ and $429 \mathrm{~m}$, which implies respective cumulated thickness of $250 \mathrm{~m}$ and $282 \mathrm{~m}$. There is no other information regarding the carbonate formations in the boreholes. They rest upon the Blue Marls Formation. Kh5 and Kh6 are separated by only $19 \mathrm{~m}$. The differences in depth of the 

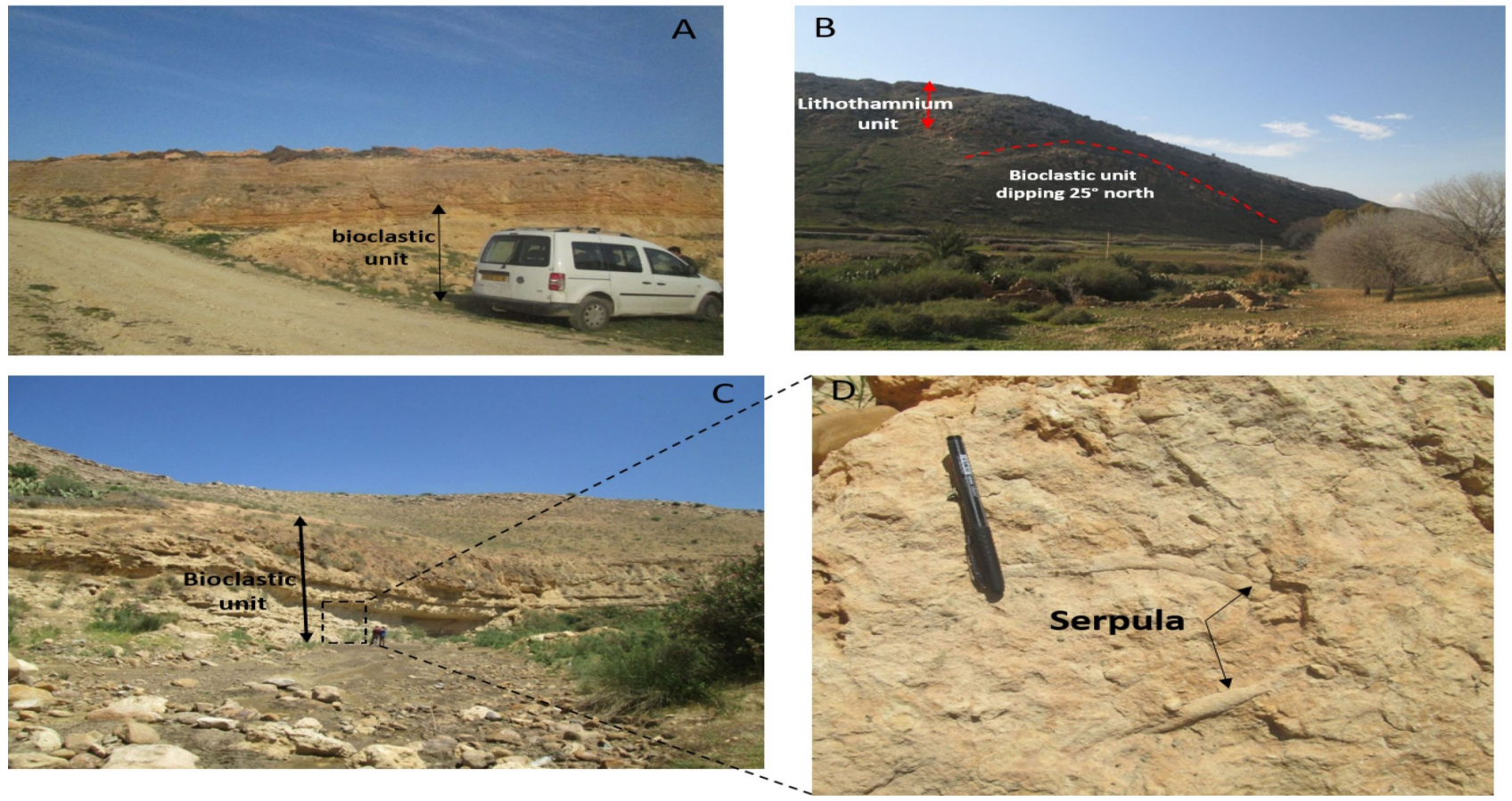

Figure 7. Structure and composition of the lower bioclastic unit. A. Horizontal bioclastic unit at the back of the platform (Section D; Figs 2, 3 , and 6 A1). B. Unconformity between sub-horizontal Lithothamnium unit and the $25^{\circ}$ dipping bioclastic unit in front of Oued Taflout (Fig. 6 A1). C \& D. The bioclastic unit characterized by Serpula fossil in Oued Taflout, in the eastern part of the study area.

carbonates would be related to post-depositional offsets in relation to the Relizane Fault Zone situated at the location.

The morphology and geometry of the upper unit can be further constrained. The topographic sections made perpendicular to the Ouarsenis piedmont show that the top of the Lithothamnium unit has a very low dip and is composed of two parts marked by a very slight $2-3^{\circ}$ increase in a surface dip about $3 \mathrm{~km}$ north of the basin (Fig. 8). The morphology of the upper unit changes slightly along the strike. Surface dip in the west is higher than in the east, which can be correlated to the difference in relief. The transition zone, which marks the change in elevation and dip, is located at the location of Oued Touchait (Fig. 8).

Using Google images, we could follow some upper beds nearly continuously from the back scarp of the carbonate formation in the south to the contact with the Quaternary alluvial sediments in the Chelif Basin to the north. We investigated the relationship between morphology and bedding. In the east, beds forming the southern part of the ramp are characterized by a very shallow dip $\left(\sim 2^{\circ}\right)$ subparallel to the topography (Pr.01 in Fig. 8). Further north, beds have a similar dip but intersect the topography forming a staircase (Fig. 6 A1A2). The $\sim 4.5^{\circ}$ dip of the carbonate relief is just steeper in the south (see swath topographic profile Pr.01 in Fig. 8). The transition zone marked by a small change in dip indicates the change between a retrograding-aggrading system to a purely aggradational system. Just west of Oued Touchait (Fig. 8), the relief increases slightly and the staircase architecture is visible along the whole length of the Lithothamnium carbonate unit. Further west where the relief is the highest, the topographic profile Pr.04 (Fig. 8) shows a slightly steeper average surface dip with again an increase from $\sim 4.5^{\circ}$ to $\sim 7.5^{\circ}$ for the northern part. The staircase morphology is pronounced for the first $\sim 2.5$ $\mathrm{km}$ of the complex starting at the contact with the Chelif alluvial deposits; at the southern end of the platform, several faults strongly affect the carbonate bedding but not the overall morphology which remains very planar (see the southern part of swath topographic profile Pr.04 in Fig. 8).

\section{Interpretation and discussion}

\subsection{Petrographic analyses}

According to the petrographic analyses and the identification of the three carbonate microfacies, characterized mainly by red algae (Lithothamnium), foraminifera, few quartz grains in some samples, and high moldic porosity, a paleoenvironmental model is proposed.

The microfacies MF1 and MF2 of this carbonate unit are typical of a carbonate ramp. MF1 is a bioclastic packstone to wackestone with microsparitic matrix and large fossils, and MF2 is a bindstone to packstone, rarely grainstone dominated by red algae. The carbonate facies and components of these two microfacies indicate a rather shallow high-energy environment above the fair-weather wave base and in an inner ramp setting (Laya \& Tucker, 2012).

MF3 is a bioclastic packstone to wackestone with tiny elements and a microsparitic matrix. The characteristics of this microfacies are related to a slightly deeper environment in the middle ramp, in the storm wave zone (Fig. 9).

The depositional model in Figure 9 and the associated fauna are typical of open marine conditions and not of a restricted environment. The occurrence of normal marine conditions is also documented in other carbonate platforms of the Chelif Basin for the carbonate unit resting upon the lower prograding bioclastic unit (Cornée et al., 1996, 2002, 2004; Saint-Martin et al., 1992, 1995, 1997).

\subsection{Cathodoluminescence and cement analysis}

In our samples, any aragonite present would have been transformed into calcite. The absence of aragonite component can be related to falling sea level that subaerially exposed the upper part of the platform.

Concerning the origin of the cements, which are largely nonluminescent, it is well known that the $\mathrm{Fe} / \mathrm{Mn}$ ratio controls the maximum intensity of luminescence (Frank et al., 1982). $\mathrm{Mn}^{2+}$ 


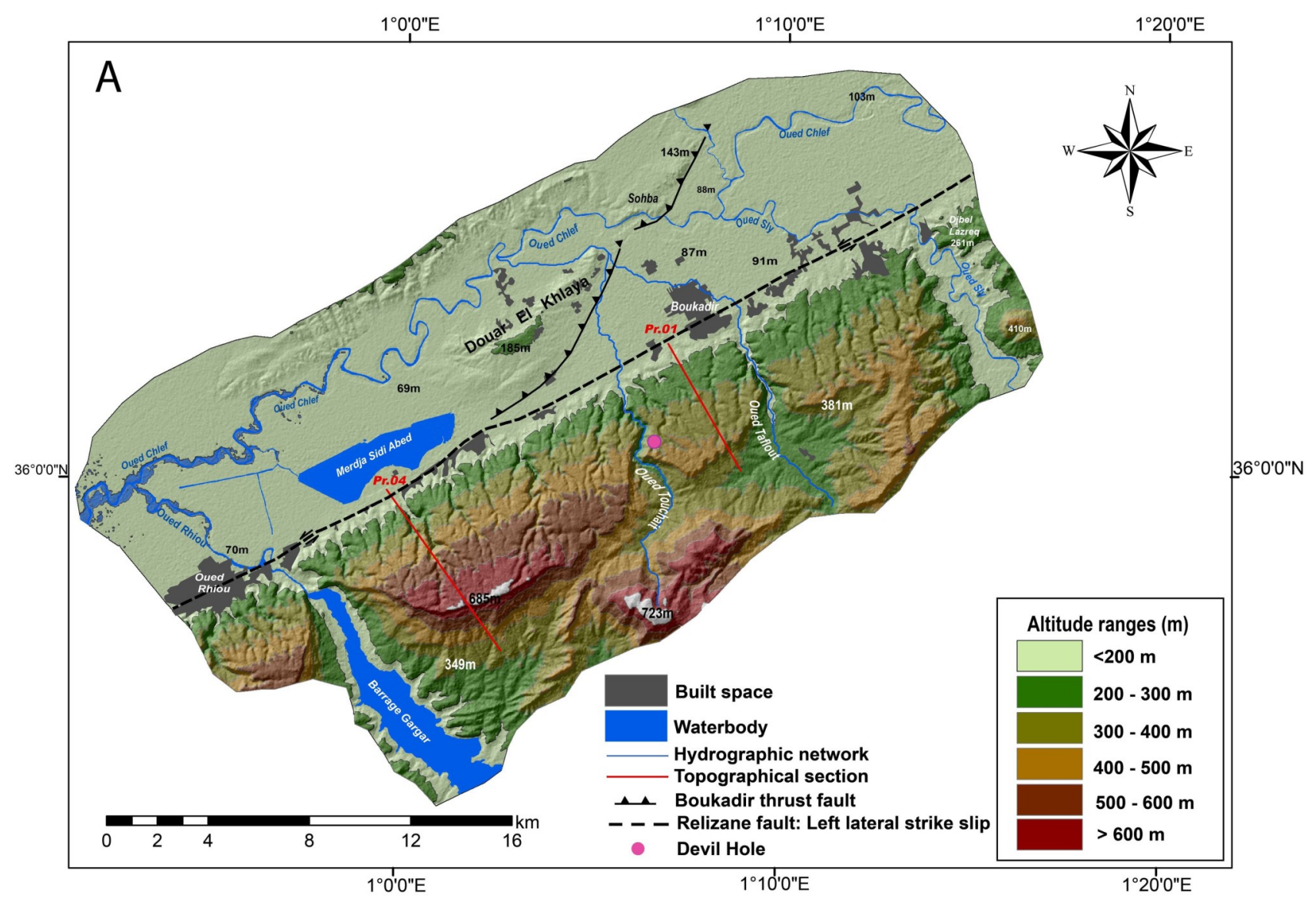

B

Swath topographic section Pr.01

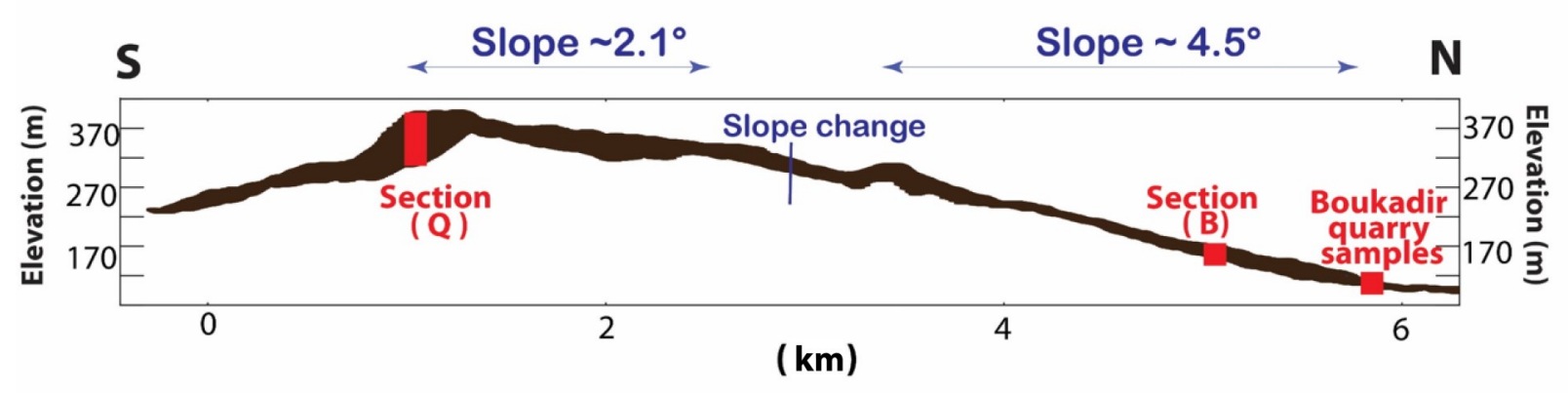

C

\section{Swath topographic section Pr.04}

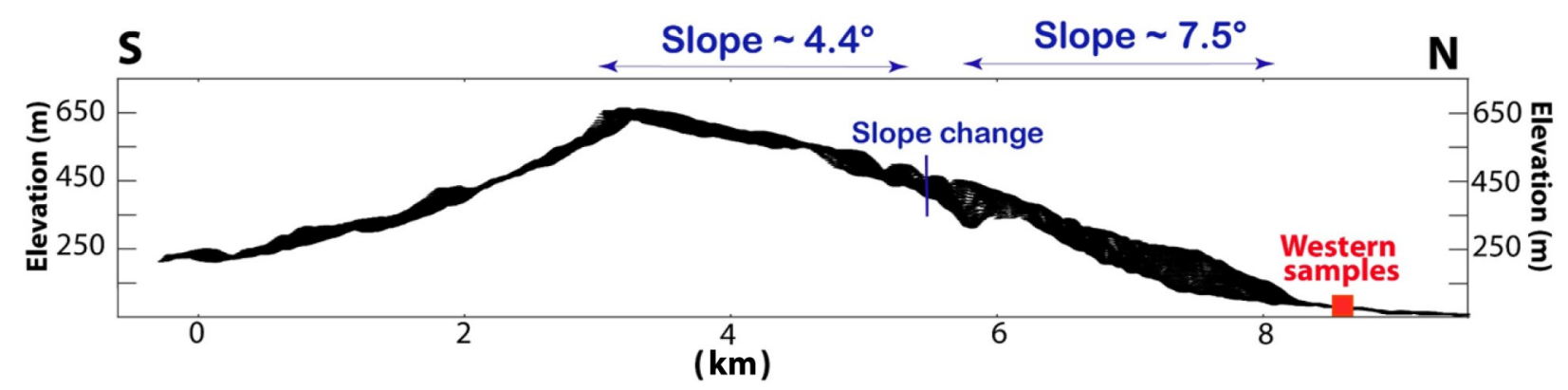

Figure 8. A. Topography of the study area and the location of the topographic sections along the piedmont. This region refers to the "Study area" in Fig. 1. B. Swath topographic profile PR.01 in the eastern part of the study area. C. Swath topographic profile PR.04 in the western part of the study area. 


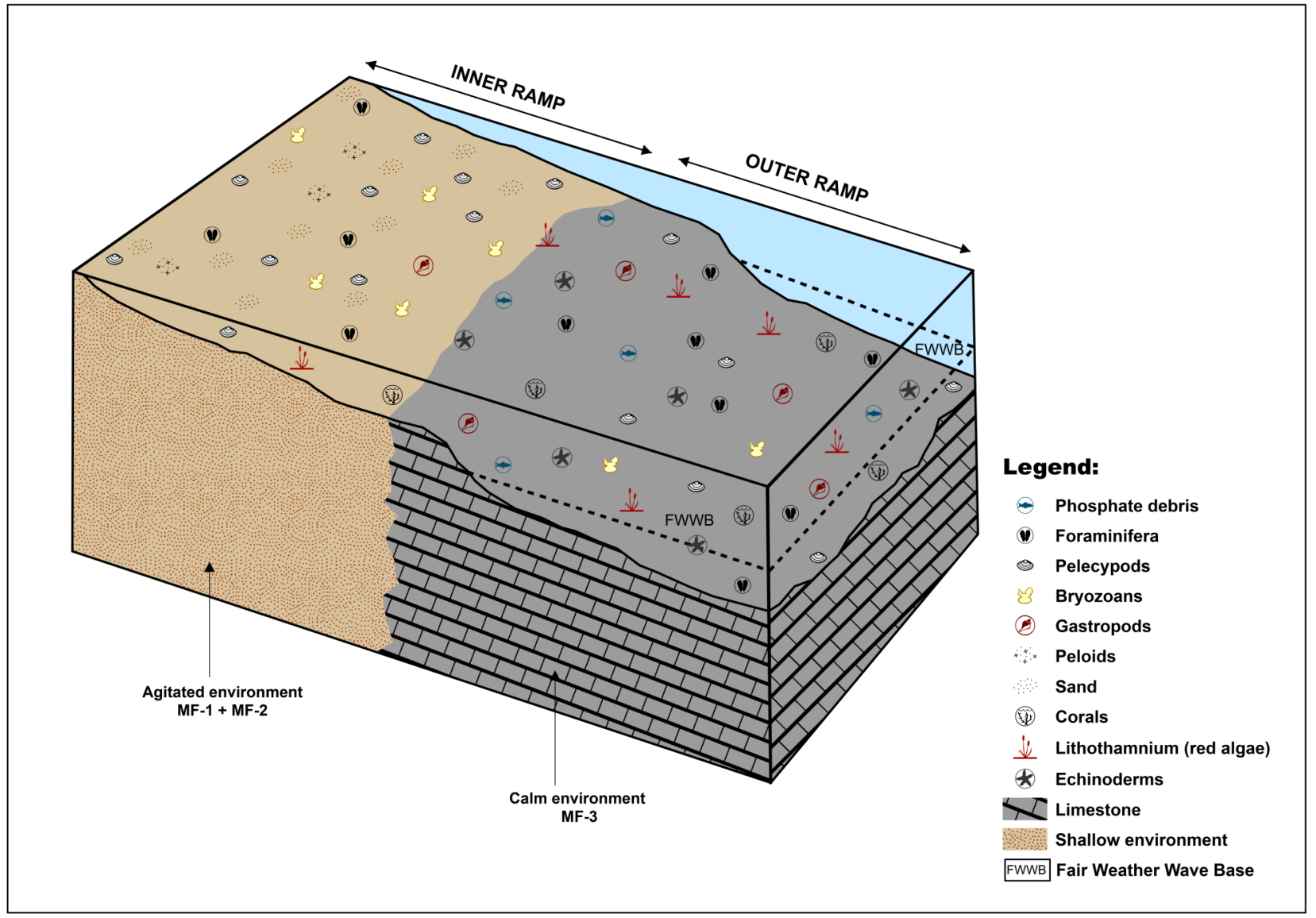

Figure 9. Depositional environment model of the terminal carbonate deposits outcropping in the Boukadir region based on the results of the petrographic analyses.

causes an orange-yellow luminescence of calcite (Meyers, 1978), while $\mathrm{Fe}^{2+}$ tends to inhibit this luminescence (Frank et al., 1982; Grover \& Read, 1983). The non-luminescence suggests widespread cementation in an oxidizing meteoric environment after a marine regression. The only example of cement zonation in the zoecia of a bryozoan may be due to a weak supply of meteoric water (the latter circulate slowly) and the onset of a very local reducing environment (Boulvain, 2001).

The platform was exposed to oxidizing meteoric water shortly after its deposition. Indeed, aerial exposure must have taken place during the Messinian Salinity Crisis (MSC). The MSC was associated with a large base-level drop in the whole Mediterranean area (Hsü et al., 1973; Ryan et al., 1973; CIESM, 2008; Mascle \& Mascle, 2019), and there was a disconnection of the Chelif marginal Basin with the main Mediterranean Basin (Saint-Martin \& Rouchy, 1990; Rouchy \& Saint-Martin, 1992; Clauzon et al., 1996; Franseen et al., 1996; Krijgsman et al., 1999; Cornée et al., 2004). In the Chelif Basin, during the MSC, up to $400 \mathrm{~m}$ of gypsum-rich deposits (Rouchy et al., 2003) were deposited in front of the studied Ouarsenis carbonate platform (Fig. 1). The gypsum resulted from a primary crystallization and was deposited in a hypersaline shallow environment (Arab et al., 2015); at that time, the carbonate platform would have been subject to subaerial exposition.

\subsection{Mineralogy and XRF analyses}

The mineralogical composition of the samples collected on the field indicates $\sim 94$ to $100 \%$ of calcite and just a few traces of quartz $(\sim 1 \%)$. It is confirmed by chemical analysis. The analyses indicate a very weak detrital flux during the development of the upper carbonate platform in the foothills of the Ouarsenis Massif. This purely carbonated ramp consisted only of biogenic autochthonous inputs.

This result is consistent with the paleogeography of the platform. The study area is located on the edge of the Ouarsenis Massif, a low emerged area at that time (Fig. 1). The carbonate formation rests entirely upon the Blue Marls Formation. The latter formation is present to the north in the Chelif Basin as indicated in Kh6 borehole (Fig. 2) and in the publication of Arab et al. (2015) based on drilling and geophysical data. It also outcrops to the south in the Ouarsenis Massif (Fig. 2). The platform near Boukadir does not seem to be anchored on a substratum high, which is probably why there was very low terrigenous input. The paleogeographic reconstruction based on Neurdin-Trescartes (1995) in Figure 10 provides a broader context. At the end of the Messinian, the uplift first occurred to the north, close to the present sea shore at the location of the Dahra Massif (Rouchy et al., 2007). The Eastern Chelif Basin during the Pliocene was still a synclinorium limited to the south by the Boukadir Messinian carbonate platform and the Relizane Fault. More than $750 \mathrm{~m}$ of Pliocene marls were deposited in this synclinorium (Fig. 1) that was uplifted and folded (Arab et al., 2015) in a later phase. This paleogeography leads to only distant terrigenous contributions. Quartz input may be linked to two different processes. First, Neurdin-Trescartes (1995) suggested the occurrence of "longshore" currents with an E-W direction, parallel to the coast, linked to the existence of high tides and the presence of swells arriving obliquely on the shore, mixing distant material (Neurdin-Trescartes, 1995). The paleogeographic map in Figure 10 indicates that distal input 


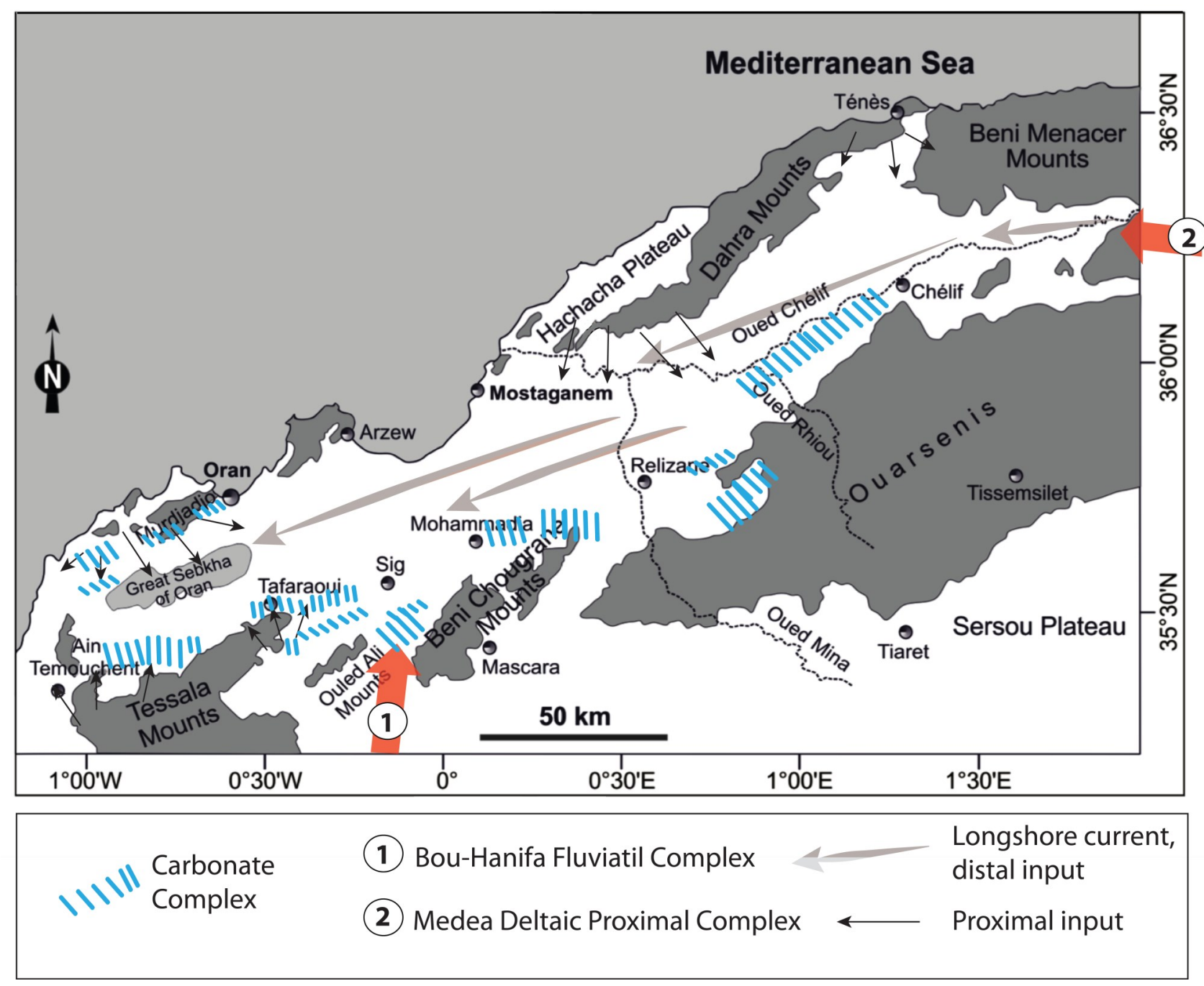

Figure 10. Paleogeographic map based on a previously published map of Neurdin-Trescartes (1992, 1995), Mansour et al. (1995), and Vinn et al. (2020).

could be linked to the Medea Deltaic complex (NeurdinTrescartes, 1995). Second, these quartz grains could also be due to an aeolian input. Some SEM analyses would be necessary to decipher their origin.

\subsection{Geometry analyses}

Our analysis allows distinguishing a lower carbonate platform and an upper carbonate ramp with different geometry. Carbonate-platform stratal geometries are the result of multiple interacting controls (Kenter, 1990; Adams et al., 2002), including sediment transport, sediment production, differential subsidence, and relative sea-level oscillations balance (Williams et al., 2011). The carbonate platform of the northern piedmont of Ouarsenis in the south of the Boukadir region, as well as the variations of slopes, show that the geometry of this platform is conditioned by several factors as studied in detail by Kenter (1990) and Adams et al. (2002). Given the limited field observations and sampling, we can only make a first order interpretation. In addition, the geometry of the lower platform is less constrained than the upper one and the lack of petrographic data prevents the assessment of its depositional environment.

The lower unit has a platform geometry characterized by a short steep front with 35 to $25^{\circ}$ dipping beds forming clinoforms as evidenced along the two largest river valleys, Oued Rhiou and Oued Taflout. The clinoforms are clearest at Oued Rhiou location (Fig. 6 A1, A2), and the carbonate unit at that location is bioclastic (section A, log of Neurdin- Trescartes, 1992). The back of the platform (section D, Fig. 3) is characterized by a low dip with a downward gradational transition to the Blue Marls Formation (Fig. 7 A), and an upward gradational transition to facies with grain size suggesting a shallow and active depositional environment (Fig. 7 A-C). We interpret this architecture as a prograding rimmed platform (Pomar et al., 1996; Adams \& Schlager, 2000; Eberli et al., 2004; Playton et al., 2010; Gao \& Fan, 2015) (Fig. 6 A1).

The upper unit has a different geometry characterized by a continuous low bedding angle over the $6 \mathrm{~km}$ outcropping at the surface and the nearly homogeneous carbonate deposition of over a thickness of least $80 \mathrm{~m}$ (Fig. $6 \mathrm{~A} 1$, section B). The bedding angle is subhorizontal $\left(<5^{\circ}\right)$ and the dip of the platform changes near the Boukadir Thrust (Fig. 8), which is interpreted to be due to later tectonic deformation. Factors controlling the slope geometry are the volume of sediment and platform height (Schlager, 1981), the erosion-deposition balance (Schlager \& Camber, 1986), and the grain size (Kirkby, 1987). The morphology suggests a nearly homoclinal ramp geometry (Ahr, 1973; Read, 1985; Burchette \& Wright, 1992). The facies and dip uniformity, and the large thickness of the upper carbonate unit suggest that it is an aggradation ramp with a production keeping up with a base level rise (Read, 1985). Strata are more aggradational at the back of the platform than at the front; the small change in dip downward marked a more pronounced retrogradational pattern, near the base of the upper carbonate 
unit (Fig. 8).

Homoclinal ramp geometry also suggests that the amount of sediment exported downslope is similar to the carbonate production rate. Williams et al. (2011) stressed that the rates of autochthonous production are a critical factor in maintaining a ramp profile. The large thickness of the carbonate ramp still suggests large productivity. The absence of gradient in productivity along the platform is in agreement with the fact that the ramp is formed only by red algae (Lithothamnium), which are poorly sensitive to changes in water depth along the ramp compared to green algae (Lüning, 1990; Lee, 1999). The difference in architecture between the lower platform and the upper homoclinal ramp suggests a strong environmental change. One key factor may be the increase in downslope transport between the two carbonate units. One hypothesis is stronger westward longshore currents (Neurdin-Trescartes, 1995) due to the water body constriction induced by the progradation in the Chelif Basin (Fig. 10). The occurrence of these paleocurrents is confirmed by magnetic indicators in the Messinian Formation more to the SE along the same piedmont (Derder et al., 2011).

Finally, given the comparable thickness of the carbonates and the similar depositional environment of the upper carbonate unit along the piedmont (Fig. $4 \mathrm{~A}$ and B) evidenced by the thin sections, the platform was deformed after its deposition. The deformation (uplift and tilt) of the platform would be related to the Relizane Fault running along the piedmont. Although this fault was mostly considered to be a left-lateral strike-slip fault by Meghraoui et al. (1986), Soumaya et al. (2018) inferred a significant reverse component and interpreted it as a typical conjugate fracture in a wide E-W crustal-scale Riedel shear fracture system. The increase in tilt and elevation of the platform to the west occurs near the termination of Boukadir Thrust close to the Relizane Fault (Fig. 2), which suggests a causal relation. We therefore believe that the present geometry of the ramp is partly related to uplift and tilt that change along the Relizane Fault. In addition, the depths of the Carbonates (Lithothamnium Limestone) at the location of Kh5 and Kh6 (Fig. 2) imply a significant vertical offset. The transpressive motion accommodated by the Relizane Fault is expected as it is part of the fault system that accommodates the oblique active convergence between Eurasia and Africa over at least the last 2.5 Ma (Meghraoui et al., 1996). Before, during the Tortonian to Messinian periods, the Chelif Basin had undergone a different transtensive deformation phase that resulted in the creation of this "postthrust" basin (Perrodon, 1957; Meghraoui, 1982; Thomas, 1985; Meghraoui et al., 1986; Domzig et al. 2006; Derder et al., 2011; Bachouche \& Boutaleb, 2013; Arab et al., 2015). Significant subsidence during the Messinian at the front of the Ouarsenis relief was indeed necessary to create the accommodation space for the deposition of the Blue Marls Formation and the two carbonate units.

\section{Correlation of carbonate platforms from the Alboran Sea region}

The Boukadir platform in the Chelif Basin is similar to other Messinian platforms in the same basin, i.e. the Traras margin reef, Sebaa Chioukh Hills (Saint-Martin, 1996), Murdjadjo (Saint-Martin, 2008), Tessala Beni Chougrane (Naimi et al., 2020), and Douar Naïmia (northwestern Algeria, Dahra Mounts) (Vinn et al., 2020). All platforms in the Chelif Basin developed on the edge of the Alboran Sea and have a large extension. They are aggrading platforms characterized by a rather flat relief. They contain small amounts of detrital sediments (Cornée et al., 2004). They were all deposited above a thick layer of Tortonian-Messinian Blue Marls (Bessedik et al., 2002), considered to be a Transgressive System Tract (TST). Above, the lower bioclastic carbonate unit is overlain by prograding coral reefs with porites and Halimeda (green algae) carbonates (Saint-Martin et al., 1992; Cornée et al., 2004; Saint-Martin, 2008; Naimi et al., 2020). This succession ends with the deposit of gradational sediments constituting the "Terminal Carbonate Complex" defined by Esteban (1979) composed of coral constructions, white micritic limestones, oolite limestones, stromatolites, and sometimes gypsum lenses (Saint-Martin, 2008).

The Boukadir carbonate formation, that we studied, still presents some differences: (1) the absence of coral reef and Halimeda limestone and of the TCC, (2) the prevalence of redalgal carbonates over a large thickness. The absence of Halimeda in the Boukadir area can be linked to two factors. First, it can indicate a lesser salinity than in the western part of the Chelif Basin and in other regions. Indeed, Halimeda deposits in Messinian carbonate platforms in Italy, Crete, and Spain are interpreted to support a high rate of salinity, which varies between 48 and 58\% (Brachert et al., 2007; Bourillot et al., 2009). Second, Halimeda is the most abundant component in the reef-slope facies (Mankiewicz, 1988; Martin et al., 1989; Reolid et al., 2014), but this environment is not visible in the investigated area.

The Boukadir platform is more than $165 \mathrm{~m}$ thick at section $\mathrm{H}$ where the two carbonate units have similar low dips and has an apparent thickness of up to $280 \mathrm{~m}$ (Kh6, Fig. 2) in the Chelif Basin. It is one of the thickest carbonate platforms around the Mediterranean Basin. It indicates steady-state subsidence, much larger than in other parts of the Chelif Basin and in the surrounding Mediterranean area. Part of the subsidence would be related to the transtensional deformation of Tortonian and Messinian periods that created the necessary accommodation space (Perrodon, 1957; Meghraoui, 1982; Thomas, 1985; Meghraoui et al., 1986; Arab et al., 2015). Another part of the subsidence may be related to the progressive compaction of the blue marls under the weight of the carbonate platform. This post-depositional process is related to the highly compactable nature of the blue marls (Wanless, 1979), and resulted from the progressive increase in the burial load due to the aggradation of the platform (Flügel, 2004). In front of the Boukadir area, the thickness of the buried blue marls reaches more than $1000 \mathrm{~m}$ (Arab et al., 2015), and at the back of the platforms, more than $500 \mathrm{~m}$ (Neurdin-Trescartes, 1992).

The similarity in the development of carbonate platforms in the Alboran Sea allowed Cornée et al. (2004) to correlate the different existing sedimentary logs and sections. We set the Boukadir platform in that context, focusing on the Southern Alboran Sea (Algeria, Morocco) (Fig. 11).

Cornée et al. (2004) proposed the following depositional history during the Messinian. The first deposits are systematically retrograding characterized by blue marls with a variable thickness. They are part of the Transgressive System Tract, T1, of the first cycle of the Messinian (Fig. 11). The retrograding $\mathrm{T} 1$ unit is generally capped by a prograding carbonate unit (T2) (Cornée et al., 1996, 2002). T1 and T2 are separated by a marine planation (erosion) surface A formed around 6.7 Ma ago (Cornée et al., 2004). T2 are generally bioclastic units with red algae and bivalves dominated by corals deposited in an open marine environment (Cornée et al., 2004). These units change into marls and diatomites basinward. T2 can be composed of different subunits, but the lower one is generally prograding and bioclastic. In northeast Morocco, in the Kebdana and Tessala-Beni Chougrane sites, T2 carbonate units revealed a general shallowing upward 


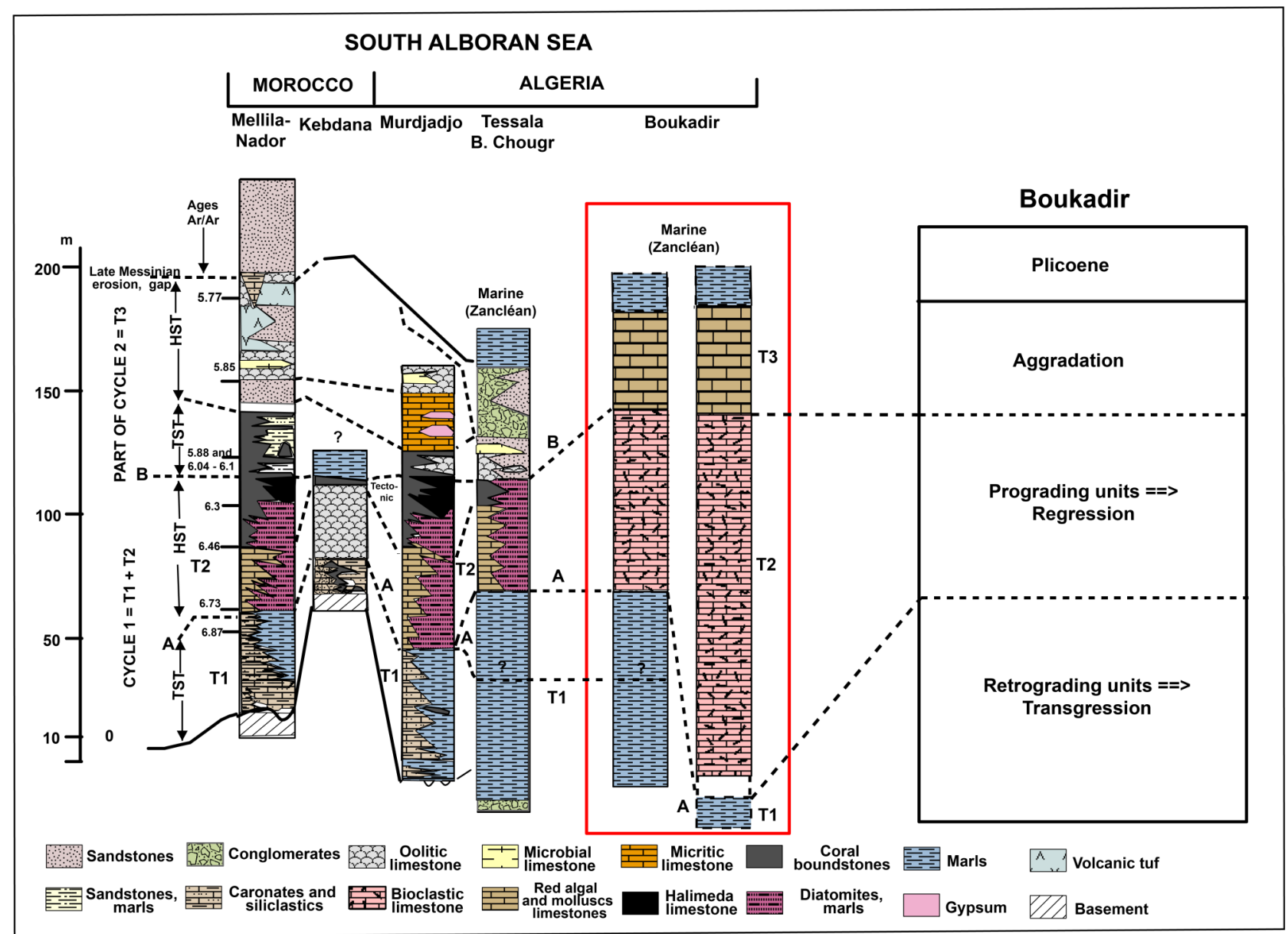

Figure 11. Proposed correlation between the South Alboran Sea Messinian carbonate platforms and the Boukadir platform; modified from Cornée et al., (2004). Mellila-Nador ages from Roger et al. (2000) and Cornée et al. (2002).

trend, which may reflect progradation (Cornée et al., 2004). The top of the prograding reef complex $\mathrm{T} 2$ is a marine planation surface B that has been systematically identified in the southern Alboran Sea. It corresponds to the beginning of the MSC at 5.95 $\mathrm{Ma}$ and indicates a limited sea-level drop according to Cornée et al. (2004). Above B, the transgressive marine shallow-water carbonate T3, known as the "Terminal Carbonate Complex" (TCC) deposits was deposited (Fig. 11). The platform geometry and its faunal content attest to a restricted very shallow water environment (Cornée et al., 2004).

In Boukadir, the lower carbonate bioclastic unit corresponds to the basal subunit of T2. It is composed of bioclastic clinoforms to the north and of nearly flat calcareous marls to the south at its base. These bioclastic carbonates were deposited in a very shallow environment with tempestite layers at their top. At this study location, surface A is not easily identifiable, because we have a gradational contact with the Blue Marls Formation (unit T1 in Fig. 11).

Regarding the upper Boukadir homoclinal ramp, the contact is not marked by a radical change in the depositional environment associated with a sea-level drop (Riding et al. 1999) nor the deposition of evaporites (Rouchy \& Saint-Martin, 1992; Rouchy et al., 2001). The thick upper Lithothamnium aggrading unit is characterized by the deposition of red algal carbonates with microsparitic matrix and a faunal content typical of an open marine environment. We therefore infer that it still corresponds to unit T2. After, our analyses suggest a rapid falling sea level that subaerially exposed the platform and trigger the transformation of all aragonite in calcite. This sea- level drop corresponds to the MSC.

\section{Conclusion}

The carbonate units that form the northern piedmont of Ouarsenis range of the Boukadir region on the southern edge of the eastern Chelif Basin represent one of the thickest Messinian carbonate platforms in the whole Mediterranean realm. Two units are present: a lower bioclastic one and an upper Lithothamnium one. Petrographic analysis of the upper unit reveals three different microfacies, characterized by Lithothamniums, foraminifera, high porosity, and a microsparitic matrix. Our study demonstrated that the Lithothamnium carbonate platform of Boukadir (Chelif Basin) developed in a high-energy environment, above the fair-weather wave base, in a shallow marine environment (inner ramp setting). Its productivity was very high, the mineralogical composition indicates a purely carbonated platform, that formed of autochthonous biogenic inputs ( 94 to $100 \%$ of calcite), with very little allochthonous fluvial input.

The geometry of the two carbonate units is different. The lower unit forms a prograding rimmed platform with $35^{\circ}$ clinoforms. Locally, it gradually evolves to the upper Lithothamnium unit that is an homoclinal ramp with a low angle and very small change in dip downwards over $6 \mathrm{~km}$. To maintain a nearly homoclinal geometry despite the high autochthonous productivity of carbonate, the export and erosion rate must be similar to the production rate. The strong export is potentially related to long-shore currents already documented by 
Neurdin-Trescartes (1995) and Derder et al. (2011) that would have intensified with the narrowing of the eastern Chelif Basin induced by the progradation of the lower carbonate platform. Finally, the facies and dip uniformity, and the large thickness of the upper Lithothamnium unit indicate an aggradation ramp with a production keeping up with a relative sea-level (RSL) rise (Read, 1985). A large component of the RSL is due to the subsidence of the underlying blue marls and to the transtensional deformation characterizing the Tortonian and Messinian periods (Arab et al., 2015). This large aggradation was followed by a rapid exhumation (regression) attested by the absence of aragonite.

The history of the platform is coherent with the others Messinian platforms of the Southern Alboran Sea, but it does not represent a complete sequence. In the classification of Cornée et al. (2004), the Boukadir platform is the T2 unit deposited between 6.7 and 5.95 Ma before the MSC. The top of the platform, which is the present-day front of the Ouarsenis Massif, marks the first sharp sea-level drop that occurred at the MSC.

\section{Acknowledgments}

The authors would like to thank Pr Guettouche Med Said, director of the Geomorphology and Geohazards (G\&G) laboratory, FSTGAT - USTHB for his help, the people of the research and development CRD of Boumerdes of Algiers for their contribution to the development of thin sections.

We would also like to thank the people who contributed to the field campaigns, in particular, Mr. Abdeldjalil Goumrassa, Mr. Sofiane Meddane, as well as the colleagues who helped with the interpretation of thin sections: Ms Samira Mendir, Ms Sarah Robinet, and M. Imen Arfaoui, and Ms Jemaa Amakrane for her contribution to the identification of fossils. An anonymous reviewer and Dr Xavier Devleeschouwer are thanked for their very constructive reviews of the manuscript.

\section{References}

Adams, E.W. \& Schlager, W., 2000. Basic types of submarine slope curvature. Journal of Sedimentary Research, 70/4, 814-828. https:// doi.org/10.1306/2DC4093A-0E47-11D7-8643000102C1865D

Adams, E.W., Morsilli, M., Schlager, W., Keim, L. \& van Hoek, T., 2002. Quantifying the geometry and sediment fabric of linear slopes: examples from the Tertiary of Italy (Southern Alps and Gargano Promontory). Sedimentary Geology, 154/1-2, 11-30. https://doi.org/10.1016/S0037-0738(02)00125-2

Ahr, W.M., 1973. Carbonate Ramp-Alternative to Shelf Model. AAPG Bulletin, 57(9), 1826-1826. https://doi.org/10.1306/83D910C916C7-11D7-8645000102C1865D

Amieux, P., 1982. Cathodoluminescence: method of sedimentological study in carbonates. Bulletin des centres de recherches explorationproduction Elf-Aquitaine, 6, 437-483.

Anderson, R.V.V., 1936. Geology in the coastal Atlas of western Algeria. Geological Society of America, Memoirs, 4, 450 p.

Arab, M., Bracene, R., Roure, F., Zazoun, R.S., Mahdjoub, Y. \& Badji, R., 2015. Source rocks and related petroleum systems of the Chelif Basin (western Tellian domain, north Algeria). Marine and Petroleum Geology, 64, 363-385. https://doi.org/10.1016/ j.marpetgeo.2015.03.017

Atif, K.F.T., Bessedik, M., Belkebir, L., Mansour, B. \& Saint-Martin, J.P., 2008. Le passage Mio-Pliocène dans le bassin du Bas Chélif (Algérie). Biostratigraphie et paléoenvironnements. Geodiversitas, 30/1, 97-116.

Azañón, J.M., Galve, J.P., Pérez-Peña, J.V., Giaconia, F., Carvajal, R., Booth-Rea, G., Jabaloy, A., Vázquez, M. \& Roldán, F.J., 2015. Relief and drainage evolution during the exhumation of the Sierra Nevada (SE Spain): Is denudation keeping pace with uplift?
Tectonophysics, 663, 19-32. https://doi.org/10.1016/ j.tecto.2015.06.015

Babinot, J.F. \& Boukli-Hacene, S., 1998. Associations d'ostracodes en faciès mixtes de plate-forme : l'exemple du Messinien de la région nord des Tessala (Oranie, Algérie). Revue de micropaléontologie, 41/1, 3-17.

Bachouche, S. \& Boutaleb, B., 2013. Geology, mineralogy, and chemistry of the M'zila bentonitic clay deposit (Mostaganem, NW Algeria). Arabian Journal of Geosciences, 6/6, 2165-2172. https:// doi.org/10.1007/s12517-011-0455-8

Baulig, H., 1926. Sur une méthode altimétrique d'analyse morphologique appliquée à la Bretagne péninsulaire. Bulletin de l'Association de Géographes Français, 3/10, 7-9.

Belhadji, A., Belkebir, L., Saint-Martin, J. P., Mansour, B., Bessedik, M. \& Conesa, G. (2008). Apports des foraminifères planctoniques à la biostratigraphie du Miocène supérieur et du Pliocène de Djebel Diss (bassin du Chélif, Algérie). Geodiversitas, 30/1, 79-96.

Belkebir, L., Bessedik, M., Ameur-Chehbeur, A. \& Anglada, R., 1996. Le Miocène des bassins nord-occidentaux d'Algérie : biostratigraphie et eustatisme. Elf Aquitaine édition, Pau, Mémoire, 16, 553-561.

Belkebir, L., Labdi, A., Mansour, B., Bessedik, M. \& Saint-Martin, J.P., 2008. Biostratigraphie et lithologie des séries serravallotortoniennes du massif du Dahra et du bassin du Chélif (Algérie). Implications sur la position de la limite serravallo-tortonienne. Geodiversitas, 30/1, 9-19.

Bessedik, M., Belkebir, L., \& Mansour, B., 2002. Révision de l'âge Miocène inférieur (au sens des anciens auteurs) des dépôts du bassin du bas Chelif (Oran, Algérie) : conséquences biostratigraphique et géodynamique. Mémoires du Service géologique de l'Algérie, 11, 167-186

Birebent, J., 1947. Rapport de spéléologie de l'Algérie : Inventaire. $1^{\mathrm{er}}$ Décembre 1947. Agence Nationale des Ressources Hydrauliques (ANRH), $13 \mathrm{p}$.

Boulvain, F., 2001. Facies architecture and diagenesis of Belgian Late Frasnian carbonate mounds. Sedimentary Geology, 145/3-4, 269294. https://doi.org/10.1016/S0037-0738(01)00152-X

Bourillot, R., Vennin, E., Kolodka, C., Rouchy, J.M., Caruso, A., Durlet, C., Chaix, C. \& Rommevaux, V., 2009. The role of topography and erosion in the development and architecture of shallow-water coral bioherms (Tortonian-Messinian, Cabo de Gata, SE Spain). Palaeogeography, Palaeoclimatology, Palaeoecology, 281/1-2, 92-114. https://doi.org/10.1016/j.palaeo.2009.07.015

Brachert, T.C., Vescogni, A., Bosellini, F.R., Reuter, M. \& MertzKraus, R., 2007. High salinity variability during the early Messinian revealed by stable isotope signatures from vermetid and Halimeda reefs of the Mediterranean region. Geologica Romana, 40, 51-66.

Brives, A. \& Ferrand, M., 1912. Carte géologique de l'Algérie 1:50,000 : 105, Charon. Alger, Service géologique de l'Algérie.

Burchette, T.P. \& Wright, V.P., 1992. Carbonate ramp depositional systems. Sedimentary Geology, 79/1-4, 3-57. https:// doi.org/10.1016/0037-0738(92)90003-A

BURGAP, 2004. Prospection géophysique à travers la région : Hamadena - Boukadir. Wilaya de Relizane. Rapport définitif. Agence Nationale des Ressources Hydrauliques (ANRH), 57 p.

CIESM, 2008. Executive summary. In Briand, F. (ed.), The Messinian Salinity Crisis from mega-deposits to microbiology: A consensus report. Commission Internationale pour 1'Exploration de la Mer Méditerranée, Monaco, CIESM Workshop Monograph, 33, 7-28. http://www.ciesm.org/online/monographs/Almeria.html, accessed 01/09/2020.

Clauzon, G., Suc, J.P., Gautier, F., Berger, A. \& Loutre, M.F., 1996. Alternate interpretation of the Messinian salinity crisis: Controversy resolved? Geology, 24/4, 363-366. https://doi.org/10.1130/00917613(1996)024<0363:AIOTMS>2.3.CO;2

Cornée, J.J., Guieu, G., Muller, J. \& Saint-Martin, J.P., 1994. Mediterranean Messinian carbonate platforms: some controlling factors. Géologie Méditerranéenne, 21/3, 45-48. 
Cornée, J.J., Saint-Martin, J.P., Conesa, G., Andre, J.P., Muller, J. \& Benmoussa, A., 1996. Anatomie de quelques plates-formes carbonatées progradantes messiniennes de Méditerranée occidentale. Bulletin de la Société géologique de France, 167, 495-508.

Cornée, J.J., Roger, S., Münch, P., Saint-Martin, J.P., Féraud, G., Conesa, G. \& Pestrea-Saint Martin, S., 2002. Messinian events: new constraints from sedimentological investigations and new 40Ar/39Ar ages in the Melilla-Nador basin (Morocco). Sedimentary Geology, 151/1-2, 127-147. https://doi.org/10.1016/ S0037-0738(01)00235-4

Cornée, J.J., Saint-Martin, J.P., Conesa, G., Münch, P., André, J.P., Saint-Martin, S. \& Roger, S., 2004. Correlations and sequence stratigraphic model for Messinian carbonate platforms of the western and central Mediterranean. International Journal of Earth Sciences (Geologische Rundschau), 93/4, 621-633. https:// doi.org/10.1007/s00531-004-0400-0

D’Agostino, N., Jackson, J.A., Dramis, F. \& Funiciello, R., 2001. Interactions between mantle upwelling, drainage evolution and active normal faulting: an example from the central Apennines (Italy). Geophysical Journal International, 147/2, 475-497. https:// doi.org/10.1046/j.1365-246X.2001.00539.x

Derder, M.E.M., Henry, B., Amenna, M., Bayou, B., Maouche, S., Besse, J., Abtout, A., Boukerbout, H., Bessedik, M., Bourouis, S. \& Ayache, M., 2011. Tectonic evolution of the active "Chelif" basin (Northern Algeria) from paleomagnetic and magnetic fabric investigations. In Schattner, U. (ed.), New Frontiers in Tectonic Research: at the Midst of Plate Convergence. IntechOpen, Rijeka (Croatia), 3-26.

Domzig, A., Yelles, K., Le Roy, C., Déverchère, J., Bouillin, J.-P., Bracène, R., Mercier de Lépinay, B., Le Roy, P., Calais, E., Kherroubi, A., Gaullier, V., Savoye., B. \& Pauc, H., 2006. Searching for the Africa-Eurasia Miocene boundary offshore western Algeria (MARADJA'03 cruise). Comptes Rendus Geoscience, 338/1-2, 80-91. https://doi.org/10.1016/j.crte.2005.11.009

Eberli, G.P., Anselmetti, F.S., Betzler, C., Van Konijnenburg, J.H. \& Bernoulli, D., 2004. Carbonate platform to basin transitions on seismic data and in outcrops: Great Bahama Bank and the Maiella platform margin, Italy. In Eberli, G.P., Masaferro, J.L. \& Sarg, J.F.R. (eds), Seismic Imaging of Carbonate Reservoirs and Systems. AAPG Memoir, 81, 207-250. https://doi.org/10.1306/M81928

Embry, A.F. \& Klovan, J.E., 1971. A late Devonian reef tract on northeastern Banks Island, NWT. Bulletin of Canadian petroleum geology, 19/4, 730-781.

Esteban, M., 1979. Significance of the upper Miocene coral reefs of the western Mediterranean. Palaeogeography, Palaeoclimatology, Palaeoecology, 29, 169-188. https://doi.org/10.1016/0031-0182(79) 90080-4

Fielding, E., Isacks, B., Barazangi, M. \& Duncan, C., 1994. How flat is Tibet? Geology, 22/2, 163-167. https://doi.org/10.1130/0091-7613 (1994)022<0163:HFIT $>2.3 . \mathrm{CO} ; 2$

Flügel, E., 2004. Microfacies analysis of carbonate rocks. Analysis, interpretation and application. Springer, Berlin, $976 \mathrm{p}$.

Frank, J.R., Carpenter, A.B. \& Oglesby, T.W., 1982. Cathodoluminescence and composition of calcite cement in the Taum Sauk Limestone (Upper Cambrian), Southeast Missouri. Journal of Sedimentary Research, 52/2, 631-638. https:// doi.org/10.1306/212F7FB8-2B24-11D7-8648000102C1865D

Franseen, E.K., Esteban, M., Ward, W.C. \& Rouchy, J.-M., 1996. Models for carbonate stratigraphy from Miocene reef complexes of Mediterranean regions: Introduction. In Franseen, E.K., Esteban, M., Ward, W.C. \& Rouchy, J.-M. (eds), Models for Carbonate Stratigraphy from Miocene Reef Complexes of Mediterranean Regions. SEPM Society for Sedimentary Geology, Tulsa, Concepts in Sedimentology and Paleontology, 5, v-ix.

Gao, Z. \& Fan, T., 2015. Carbonate platform-margin architecture and its influence on Cambrian-Ordovician reef-shoal development, Tarim Basin, NW China. Marine and Petroleum Geology, 68, 291-306. https://doi.org/10.1016/j.marpetgeo.2015.08.033
Grohmann, C.H., 2005. Trend-surface analysis of morphometric parameters: a case study in southeastern Brazil. Computers \& geosciences, 31/8, 1007 1014. https://doi.org/10.1016/j.cageo.2005.02.011

Grover Jr, G. \& Read, J.F., 1983. Paleoaquifer and deep burial related cements defined by regional cathodoluminescent patterns, Middle Ordovician carbonates, Virginia. AAPG bulletin, 67/8, 1275-1303. https://doi.org/10.1306/03B5B73B-16D1-11D7$8645000102 \mathrm{C} 1865 \mathrm{D}$

Hemming, N.G., Meyers, W.J. \& Grams, J.C., 1989. Cathodoluminescence in diagenetic calcites; the roles of $\mathrm{Fe}$ and $\mathrm{Mn}$ as deduced from electron probe and spectrophotometric measurements. Journal of sedimentary research, 59/3, 404-411. https://doi.org/10.1306/212F8FA8-2B24-11D7$8648000102 \mathrm{C} 1865 \mathrm{D}$

Hsü, K.J., Cita, M.B. \& Ryan, W.B.F., 1973. The origin of the Mediterranean evaporites. In Ryan, W.B.F., Hsü, K.J. et al., Initial Reports of Deep Sea Drilling Project. U.S. Government Printing Office, Washington, 13, 1203-1231. https://doi.org/10.2973/ dsdp.proc.13.143.1973

Hsü, K.J., Montadert, L., Bernoulli, D., Cita, M.B., Erickson, A., Garrison, R.E., Kidd, R.B., Mèlierés, F., Müller, C. \& Wright, R., 1977. History of the Mediterranean salinity crisis. Nature, 267/5610, 399-403. https://doi.org/10.1038/267399a0

Jarvis, A., Reuter, H.I., Nelson, A. \& Guevara, E., 2008. Hole-filled seamless SRTM data V4. International Centre for Tropical Agriculture (CIAT). https://srtm.csi.cgiar.org, accessed 21/05/2019.

Kenter, J.A., 1990. Carbonate platform flanks: slope angle and sediment fabric. Sedimentology, 37/5, 777-794. https://doi.org/10.1111/ j.1365-3091.1990.tb01825.x

Kirkby, M.J., 1987. General models of long-term slope evolution through mass movement. In Anderson, M.G. \& Richards, K.S. (eds), Slope Stability: Geotechnical Engineering and Geomorphology. John Wiley \& Sons, Chichester, 359-379.

Krijgsman, W., Hilgen, F.J., Raffi, I., Sierro, F.J. \& Wilson, D.S., 1999. Chronology, causes and progression of the Messinian salinity crisis. Nature, 400/6745, 652-655. https://doi.org/10.1038/23231

Krijgsman, W., Capella, W., Simon, D., Hilgen, F.J., Kouwenhoven, T.J., Meijer, P.T., Sierro, F.J., Tulbure, M.A., van den Berg, B.C.J, van der Schee, M. \& Flecker, R., 2018. The Gibraltar corridor: Watergate of the Messinian salinity crisis. Marine Geology, 403, 238-246. https://doi.org/10.1016/j.margeo.2018.06.008

Laya, J.C. \& Tucker, M.E., 2012. Facies analysis and depositional environments of Permian carbonates of the Venezuelan Andes: Palaeogeographic implications for Northern Gondwana. Palaeogeography, Palaeoclimatology, Palaeoecology, 331, 1-26. https://doi.org/10.1016/j.palaeo.2012.02.011

Lee, R.E., 1999. Phycology. $3^{\text {rd }}$ ed. Cambridge University Press, Cambridge, $614 \mathrm{p}$.

Leprêtre, R., de Lamotte, D.F., Combier, V., Gimeno-Vives, O., Mohn, G. \& Eschard, R., 2018. The Tell-Rif orogenic system (Morocco, Algeria, Tunisia) and the structural heritage of the southern Tethys margin. BSGF - Earth Sciences Bulletin, 189, 10. https:// doi.org/10.1051/bsgf/2018009

Lüning, K., 1990. Seaweeds: their environment, biogeography, and ecophysiology. John Wiley \& Sons, New York, 489 p.

Mankiewicz, C., 1988. Occurrence and paleocologic significance of Halimeda in late Miocene reefs, southeastern Spain. Coral Reefs, 6/3-4, 271-279. https://doi.org/10.1007/BF00302023

Mansour, B., Moissette, P., Noël, D. \& Rouchy, J.M., 1995. L'enregistrement par les associations de diatomées des environnements messiniens: l'exemple de la coupe de Sig (Bassin du Chélif-Algérie) Geobios, 28/3, 261-279. https://doi.org/10.1016/S0016-6995(95) 80001-8

Mansour, B., Bessedik, M., Saint-Martin, J.P. \& Belkebir, L., 2008 Signification paléoécologique des assemblages de diatomées du Messinien du Dahra sud-occidental (bassin du Chélif, Algérie nordoccidentale). Geodiversitas, 30/1, 117-139. 
Martin, J.M., Braga, J.C. \& Rivas, P., 1989. Coral successions in Upper Tortonian reefs in SE Spain. Lethaia, 22/3, 271-286. https:// doi.org/10.1111/j.1502-3931.1989.tb01342.x

Mascle, G. \& Mascle, J., 2019. The Messinian salinity legacy: 50 years later. Mediterranean Geoscience Reviews, 1, 5-15. https:// doi.org/10.1007/s42990-019-0002-5

Meghraoui, M., 1982. Etude néotectonique de la région nord-est d'El Asnam : Relation avec le séisme du 10 Octobre 1980. Thèse de $3^{\mathrm{e}}$ cycle, Université de Paris VII, Paris, 210 p.

Meghraoui, M., Cisternas, A. \& Philip, H., 1986. Seismotectonics of the lower Cheliff basin: structural background of the El Asnam (Algeria) earthquake. Tectonics, 5/6, 809-836. https:// doi.org/10.1029/TC005i006p00809

Meghraoui, M., Morel, J.L., Andrieux, J. \& Dahmani, M., 1996. Tectonique plio-quaternaire de la chaine tello-rifaine et de la mer d'Alboran ; une zone complexe de convergence continent-continent. Bulletin de la Société géologique de France, 167/1, 141-157.

Meyers, W.J., 1978. Carbonate cements: their regional distribution and interpretation in Mississippian limestones of southwestern New Mexico. Sedimentology, 25/3, 371-400. https://doi.org/10.1111/ j.1365-3091.1978.tb00318.x

Moissette, P., 1988. Faunes de bryozoaires du Messinien d'Algérie occidentale. Documents des Laboratoires de Géologie de Lyon, $102,351 \mathrm{p}$.

Moissette, P., 1993. Bryozoan assemblages in Messinian deposits of western Algeria. Lethaia, 26/3, 247-259. https://doi.org/10.1111/ j.1502-3931.1993.tb01527.x

Molin, P., Pazzaglia, F.J. \& Dramis, F., 2004. Geomorphic expression of active tectonics in a rapidly-deforming forearc, Sila massif, Calabria, southern Italy. American journal of science, 304/7, 559589. https://doi.org/10.2475/ajs.304.7.559

Molin, P., Fubelli, G., Nocentini, M., Sperini, S., Ignat, P., Grecu, F. \& Dramis, F., 2012. Interaction of mantle dynamics, crustal tectonics, and surface processes in the topography of the Romanian Carpathians: A geomorphological approach. Global and planetary change, 90, 58-72. https://doi.org/10.1016/j.gloplacha.2011.05.005

Montenat C. \& Ott D'Estevou P., 1994. Caractères morphostructuraux des plates-formes messiniennes dans les bassins bétiques. Interim Colloquium R.C.M.N.S., Marseille, 3-6 mai 1994, Résumés, p. 37.

Moore, D.M. \& Reynolds Jr, R.C., 1989. X-ray Diffraction and the Identification and Analysis of Clay Minerals. Oxford University Press, Oxford, $332 \mathrm{p}$.

Naimi, M.N., Mansour, B. \& Cherif, A., 2020. First record of the Halimeda-rich beds from the Tessala-Beni Chougrane Messinian carbonate platform (Lower Chelif basin, NW Algeria). GeoConvention 2020, Calgary, Canada, May 11-13 2020, 5 p.

Neurdin-Trescartes, J., 1979. Paléogéographie de la marge sud du bassin du Chélif au Miocène. Comparaison entre les Tessala et les BeniChougrane (Algérie). $7^{\text {ème }}$ Réunion annuelle des Sciences de la Terre, Lyon, Résumés, p. 343.

Neurdin-Trescartes, J., 1992. Le remplissage sédimentaire du bassin néogène $\mathrm{du}$ Chelif, modèle de référence de bassins intramontagneux. Thèse de Doctorat ès-Sciences, Université de Pau et des Pays de l'Adour, France, 605 p.

Neurdin-Trescartes, J., 1995. Paléogéographie du Bassin du Chélif (Algérie) au Miocène. Causes et conséquences. Géologie Méditerranéenne, 22/2, 61-71.

Pellegrino, L., Pierre, F.D., Natalicchio, M. \& Carnevale, G., 2018. The Messinian diatomite deposition in the Mediterranean region and its relationships to the global silica cycle. Earth-Science Reviews, 178, 154-176. https://doi.org/10.1016/j.earscirev.2018.01.018

Perrodon, A., 1957. Etude géologique des bassins néogènes sublittoraux de l'Algérie occidentale. Publications du Service de la Carte géologique de l'Algérie, n.s., Bulletin, 12, 345 p.

Playton, T.E., Janson, X., Kerans, C., James, N.P. \& Dalrymple, R.W., 2010. Carbonate slopes. Facies models, 4, 449-476.

Pomar, L., Ward, W.C. \& Green, D.G., 1996. Upper Miocene Reef Complex of the Llucmajor area, Mallorca, Spain. In Franseen, E.K.,
Esteban, M., Ward, W.C. \& Rouchy, J.-M. (eds), Models for Carbonate Stratigraphy from Miocene Reef Complexes of Mediterranean Regions. SEPM Society for Sedimentary Geology, Tulsa, Concepts in Sedimentology and Paleontology, 5, 191-225.

Read, J.F., 1985. Carbonate platform facies models. AAPG bulletin, 69/1, 1-21. https://doi.org/10.1306/AD461B79-16F7-11D7$8645000102 \mathrm{C} 1865 \mathrm{D}$

Reolid, J., Betzler, C., Braga, J.C., Martín, J.M., Lindhorst, S. \& Reijmer, J.J., 2014. Reef slope geometries and facies distribution: controlling factors (Messinian, SE Spain). Facies, 60/3, 737-753. https://doi.org/1007/s10347-014-0406-4

Riding, R., Braga, J.C. \& Martín, J.M., 1999. Late Miocene Mediterranean desiccation: topography and significance of the 'Salinity Crisis' erosion surface on-land in southeast Spain. Sedimentary Geology, 123/1-2, 1-7. https://doi.org/10.1016/S00370738(98)00115-8

Riquelme, R., Martinod, J., Hérail, G., Darrozes, J. \& Charrier, R., 2003. A geomorphological approach to determining the Neogene to Recent tectonic deformation in the Coastal Cordillera of northern Chile (Atacama). Tectonophysics, 361/3-4, 255-275. https:// doi.org/10.1016/S0040-1951(02)00649-2

Roger, S., Münch, P., Cornée, J.J., Saint-Martin, J.P., Féraud, G., Pestrea, S., Conesac, G., Ben Moussa, A., 2000. ${ }^{40} \mathrm{Ar} /{ }^{39} \mathrm{Ar}$ dating of the pre-evaporitic Messinian marine sequences of the Melilla basin (Morocco): a proposal for some biosedimentary events as isochrons around the Alboran Sea. Earth and Planetary Science Letters, 179/1, 101-113. https://doi.org/10.1016/S0012-821X(00)00094-7

Rouchy, J.-M., 1982. La genèse des évaporites messiniennes de Méditerranée. Mémoires du Muséum National d'Histoire Naturelle, Série C, 50, $267 \mathrm{p}$.

Rouchy, J.-M. \& Saint-Martin, J.-P., 1992. Late Miocene events in the Mediterranean as recorded by carbonate-evaporite relations. Geology, 20/7, 629-632. https://doi.org/10.1130/0091-7613(1992) 020<0629:LMEITM $>2.3$. CO; 2

Rouchy, J.-M., Orszag-Sperber, F., Blanc-Valleron, M.-M., Pierre, C., Rivière, M., Combourieu-Nebout, N. \& Panayides, I., 2001. Paleoenvironmental changes at the Messinian-Pliocene boundary in the eastern Mediterranean (southern Cyprus basins): significance of the Messinian Lago-Mare. Sedimentary Geology, 145/1-2, 93-117. https://doi.org/10.1016/S0037-0738(01)00126-9

Rouchy, J.-M., Pierre, C., Et-Touhami, M., Kerzazi, K., Caruso, A. \& Blanc-Valleron, M.-M., 2003. Late Messinian to Early Pliocene paleoenvironmental changes in the Melilla Basin (NE Morocco) and their relation to Mediterranean evolution. Sedimentary Geology, 163/1-2, 1-27. https://doi.org/10.1016/S0037-0738(03) 00157-X

Rouchy, J.-M., Caruso, A., Pierre, C., Blanc-Valleron, M.-M. \& Bassetti, M.A., 2007. The end of the Messinian salinity crisis: evidences from the Chelif Basin (Algeria). Palaeogeography, Palaeoclimatology, Palaeoecology, 254/3-4, 386-417. https:// doi.org/10.1016/j.palaeo.2007.06.015

Roveri, M., Flecker, R., Krijgsman, W., Lofi, J., Lugli, S., Manzi, V., Sierro, F.J., Bertini, A., Camerlenghi, A., De Langej, G., Govers, R., Hilgen, F.J., Hübscher, C., Meijer, P.Th. \& Stoica, M., 2014. The Messinian Salinity Crisis: past and future of a great challenge for marine sciences. Marine Geology, 352, 25-58. https:// doi.org/10.1016/j.margeo.2014.02.002

Ryan, W.B.F., Hsü, K.J., Cita, M.B., Dumitrica, P., Lort, J., Maync, W., Nesteroff, W.D., Pautot, P., Stradner, H. \& Wezel, F.C., 1973. Balearic Rise - Site 124. In Ryan, W.B.F., Hsü, K.J. et al., Initial Reports of the Deep Sea Drilling Project. U.S. Government Printing Office, Washington, 13, 133-174. https://doi.org/10.2973/ dsdp.proc.13.106.1973

Saint-Martin, J.-P., 1996. Messinian coral reefs of western Orania, Algeria. In Franseen, E.K., Esteban, M., Ward, W.C., Rouchy, J.M. (eds), Models for Carbonate Stratigraphy from Miocene Reef Complexes of Mediterranean Regions. SEPM Society for 
Sedimentary Geology, Tulsa, Concepts in Sedimentology and Paleontology, 5, 239-246.

Saint-Martin, J.-P., 2008. Biodiversité dans les calcaires micritiques blancs des plates-formes messiniennes d'Algérie. Geodiversitas, 30/1, 165-179.

Saint-Martin, J.-P., Chaix, C. \& Moisette, P., 1983. Le Messinien récifal d'Oranie (Algérie): une mise au point. Comptes Rendus des Séances de l'Académie des Sciences, Série 2, 297/6, 545-547.

Saint-Martin, J.-P. \& Rouchy, J.-M., 1990. Les plates-formes carbonatées messiniennes en Méditerranée occidentale; leur importance pour la reconstitution des variations du niveau marin au Miocène terminal. Bulletin de la Société géologique de France, 6/1, 83-94.

Saint-Martin, J.-P., Cornée, J.-J., Conesa, G., Bessedik, M., Belkebir, L., Mansour, B., Moisette, P. \& Anglada, R., 1992. Un dispositif particulier de plate-forme carbonatée messénienne : la bordure méridionale du bassin du Bas-Chelif Algérie. Comptes Rendus de 1'Académie des Sciences, Série 2a, Sciences de la Terre et des Planètes, 315, 1365-1372.

Saint-Martin, J.-P., Cornée, J.-J., \& Muller, J., 1995. Nouvelles données sur le système de plate-forme carbonatée du Messinien des environs d'Oran (Algérie). Conséquences. Comptes Rendus de l'Académie des Sciences, Série 2a, Sciences de la Terre et des Planètes, 320, 837-843.

Saint-Martin, J.-P., Cornée, J.-J, Muller, J., Conesa, G. \& André, J.-P., 1997. Les constructions microbiennes du Messinien de Méditerranée. Geobios, 30, 463-470. https://doi.org/10.1016/S0016-6995(97)80052-6

Schlager, W., 1981. The paradox of drowned reefs and carbonate platforms. Geological Society of America Bulletin, 92/4, 197-211. https://doi.org/10.1130/0016-7606(1981)

92<197:TPODRA $>2.0 . \mathrm{CO} ; 2$

Schlager, W. \& Camber, O., 1986. Submarine slope angles, drowning unconformities, and self-erosion of limestone escarpments. Geology, 14/9, 762-765. https://doi.org/10.1130/0091-7613(1986) 14<762:SSADUA $>2.0 . \mathrm{CO} ; 2$

Scotti, V.N., Molin, P., Faccenna, C., Soligo, M. \& Casas-Sainz, A., 2014. The influence of surface and tectonic processes on landscape evolution of the Iberian Chain (Spain): Quantitative geomorphological analysis and geochronology. Geomorphology, 206, 37-57. https://doi.org/10.1016/j.geomorph.2013.09.017

Soumaya, A., Ben Ayed, N., Rajabi, M., Meghraoui, M., Delvaux, D., Kadri, A., Ziegler, M., Said Maouche, S. \& Braham, A., 2018. Active faulting geometry and stress pattern near complex strike-slip systems along the Maghreb region: Constraints on active convergence in the Western Mediterranean. Tectonics, 37/9, 3148 3173. https://doi.org/10.1029/2018TC004983

Swart, P.K., 2015. The geochemistry of carbonate diagenesis: The past, present and future. Sedimentology, 62/5, 1233-1304. https:// doi.org/10.1111/sed.12205

Thomas, G., 1985. Géodynamique d'un bassin intramontagneux : Le Bassin du Bas-Chelif occidental (Algérie) durant le Mio-PlioQuaternaire. Unpublished Ph.D. Thesis, Université de Pau et des Pays de l'Adour, France, 594 p.

Tricart, J. \& Cailleux, A., 1958. Cours de géomorphologie. Introduction à la géomorphologie climatique. Centre de documentation universitaire, Paris, $222 \mathrm{p}$.

Vinn, O., Bendella, M., Benyoucef, M., Zhang, L.J., Bouchemla, I., Ferré, B. \& Lagnaoui, A., 2020. Abundant Zoophycos and Chondrites from the Messinian (Upper Miocene) of northwestern Algeria. Journal of African Earth Sciences, 171, 103921. https:// doi.org/10.1016/j.jafrearsci.2020.103921

Wanless, H.R., 1979. Limestone response to stress; pressure solution and dolomitization. Journal of Sedimentary Research, 49/2, 437-462. https://doi.org/10.1306/212F7766-2B24-11D7-8648000102C1865D

Williams, H.D., Burgess, P.M., Wright, V.P., Della Porta, G. \& Granjeon, D., 2011. Investigating carbonate platform types: multiple controls and a continuum of geometries. Journal of Sedimentary Research, 81/1, 18-37. http://dx.doi.org/10.2110/jsr.2011.6

Manuscript received 06.03.2020, accepted in revised form 26.05.2021, available online 30.08.2021. 
Appendix. Sample location with the identification number, the geographic coordinates, and the altitude in meter.

\begin{tabular}{|c|c|c|c|}
\hline \multirow{2}{*}{ Samples } & \multicolumn{2}{|c|}{ Geographic coordinates } & \multirow{2}{*}{ Elevation (m) } \\
\hline & Longitude & Latitude & \\
\hline $\mathrm{ECHO1}$ & $0^{\circ} 58^{\prime} 12.02 " \mathrm{E}$ & $35^{\circ} 58^{\prime} 46.82^{\prime \prime} \mathrm{N}$ & 134 \\
\hline $\mathrm{ECHO2}$ & $0^{\circ} 57^{\prime} 18.88 " \mathrm{E}$ & $35^{\circ} 58^{\prime} 29.75^{\prime \prime} \mathrm{N}$ & 90 \\
\hline $\mathrm{ECHO3}$ & $0^{\circ} 56^{\prime} 40.36 " \mathrm{E}$ & $35^{\circ} 57^{\prime} 56.52^{\prime \prime} \mathrm{N}$ & 85 \\
\hline $\mathrm{ECHO} 4$ & $0^{\circ} 56$ '34.48"E & $35^{\circ} 58^{\prime} 02.35^{\prime \prime N}$ & 90 \\
\hline $\mathrm{ECHO5}$ & 056'45.19"E & $35^{\circ} 57^{\prime} 55.55^{\prime \prime} \mathrm{N}$ & 78 \\
\hline $\mathrm{ECHO6}$ & $0^{\circ} 56^{\prime} 17.91 " \mathrm{E}$ & $35^{\circ} 58^{\prime} 06.97^{\prime \prime} \mathrm{N}$ & 70 \\
\hline $\mathrm{ECHO7}$ & $1^{\circ} 10^{\prime} 40.34^{\prime \prime E}$ & $36^{\circ} 04^{\prime} 21.93^{\prime \prime N}$ & 132 \\
\hline $\mathrm{ECHO8}$ & $1^{\circ} 08^{\prime} 58.00 " \mathrm{E}$ & $36^{\circ} 02^{\prime} 49.06^{\prime \prime} \mathrm{N}$ & 150 \\
\hline 153 & $1^{\circ} 08^{\prime} 24.38^{\prime \prime} \mathrm{E}$ & $36^{\circ} 03^{\prime} 15.26^{\prime \prime} \mathrm{N}$ & 142 \\
\hline 154 & $1^{\circ} 08^{\prime} 33.25^{\prime \prime E}$ & $36^{\circ} 03^{\prime} 17.18^{\prime \prime} \mathrm{N}$ & 140 \\
\hline 156 & $1^{\circ} 08^{\prime} 35.05^{\prime \prime E}$ & $36^{\circ} 03^{\prime} 13.71^{\prime \prime} \mathrm{N}$ & 145 \\
\hline PVROO & $1^{\circ} 08^{\prime} 39.01^{\prime \prime E}$ & $36^{\circ} 03^{\prime} 06.76^{\prime \prime} \mathrm{N}$ & 161 \\
\hline PVR01 & $1^{\circ} 08^{\prime} 38.87^{\prime \prime E}$ & $36^{\circ} 03^{\prime} 04.79^{\prime \prime} \mathrm{N}$ & 166 \\
\hline PVR02 & $1^{\circ} 08^{\prime} 41.03^{\prime \prime} \mathrm{E}$ & $36^{\circ} 03^{\prime} 05.18^{\prime \prime} \mathrm{N}$ & 158 \\
\hline PVR03 & $1^{\circ} 08^{\prime} 42.54^{\prime \prime} \mathrm{E}$ & $36^{\circ} 03^{\prime} 05.72^{\prime \prime} \mathrm{N}$ & 148 \\
\hline PVR04 & $1^{\circ} 08^{\prime} 43.68 " \mathrm{E}$ & $36^{\circ} 03^{\prime} 06.04^{\prime \prime} \mathrm{N}$ & 138 \\
\hline PVR05 & $1^{\circ} 08^{\prime} 44.77^{\prime \prime E}$ & $36^{\circ} 03^{\prime} 06.48^{\prime \prime} \mathrm{N}$ & 128 \\
\hline PVR06 & $1^{\circ} 08^{\prime} 45.67 " \mathrm{E}$ & $36^{\circ} 03^{\prime} 07.24^{\prime \prime} \mathrm{N}$ & 118 \\
\hline PVR07 & $1^{\circ} 08^{\prime} 47.53^{\prime \prime} \mathrm{E}$ & $36^{\circ} 03^{\prime} 08.36^{\prime \prime} \mathrm{N}$ & 108 \\
\hline
\end{tabular}

